\title{
Economic Analysis for Ecosystem Service Assessments
}

\author{
Ian J. Bateman • Georgina M. Mace • \\ Carlo Fezzi • Giles Atkinson • Kerry Turner
}

Accepted: 2 May 2010 / Published online: 13 October 2010

(C) The Author(s) 2010. This article is published with open access at Springerlink.com

\begin{abstract}
The paper seeks to contribute to the expanding literature on ecosystem service assessment by considering its integration with economic analyses of such services. Focussing upon analyses for future orientated policy and decision making, we initially consider a single period during which ecological stocks are maintained at sustainable levels. The flow of ecosystems services and their contribution to welfare bearing goods is considered and
\end{abstract}

We are grateful for comments from two anonymous referees, Sir Partha Dasgupta (Cambridge) and Karl-Göran Mäler (Beijer Institute) of the UK NEA Economics Advisory Board, Brett Day (UEA), Ed Barbier (Wyoming), Grischa Perino (UEA), Kirk Hamilton (World Bank), Jules Pretty (Essex) and all members of the wider UK NEA economics team, especially Nicola Beaumont (Plymouth); Katherine Bolt (RSPB); Brendan Fisher (Princeton); Nick Hanley (Stirling); Andreas Kontoleon (Cambridge); Pushpam Kumar (Liverpool); David Maddison (Birmingham); Dominic Moran (SAC); Joe Morris (Cranfield); Susana Mourato (LSE); Unai Pascual (Cambridge); Steve Polasky (Minnesota); Daan van Soest (Tilburg \& VU Amsterdam); Gregory Valatin (Forestry Research, Scotland) and Bhaskar Vira (Cambridge). Opinions and remaining errors are the sole responsibility of the authors. The UK NEA is co-chaired by Defra's Chief Scientific Adviser, Professor Robert Watson (previous Chair of the Millennium Ecosystem Assessment), and by Professor Steve Albon of the Macaulay Institute. UNEP-WCMC are the UK NEA secretariat from which we are grateful to Claire Brown for comments and Lucy Simpson and Megan Tierney for support.

I. J. Bateman $(\varangle) \cdot$ C. Fezzi · K. Turner

Centre for Social and Economic Research on the Global Environment (CSERGE),

School of Environmental Sciences, University of East Anglia (UEA), Norwich NR4 7TJ, UK

e-mail: i.bateman@uea.ac.uk

I. J. Bateman

University of Western Australia, Perth, Australia

I. J. Bateman

University of Waikato, Hamilton, New Zealand

G. M. Mace

Centre for Population Biology, Imperial College London, Silwood Park, Ascot, UK

G. Atkinson

Department of Geography and Environment and Grantham Research Institute on Climate Change and Environment, London School of Economics and Political Science, London, UK 
methods for valuing resultant benefits are reviewed and illustrated via a case study of land use change. We then broaden our time horizon to discuss the treatment of future costs and benefits. Finally we relax our sustainability assumption and consider economic approaches to the incorporation of depleting ecological assets with a particular focus upon stocks which exhibit thresholds below which restoration is compromised.

Keywords Ecosystem services $\cdot$ Economic valuation $\cdot$ Stocks and flows · Wellbeing · Spatial and temporal issues · Sustainability · Irreversibility · UK National Ecosystem Assessment (UK NEA)

\section{JEL Classification $\mathrm{Q} 01 \cdot \mathrm{Q} 10 \cdot \mathrm{Q} 20 \cdot \mathrm{Q} 30 \cdot \mathrm{Q} 51 \cdot \mathrm{Q} 56 \cdot \mathrm{Q} 57$}

\section{Introduction}

The crucial role which natural systems play in underpinning economic activity and anthropocentric wellbeing is of growing concern as evidence mounts of the increasing pressures being placed upon such systems by human activity (GEF 1998; Chapin et al. 2000; Koziell 2001; MA 2005; CBD 2006; Loreau et al. 2006). One reflection of that concern is the recent undertaking of major global assessments of the status of the services provided by ecosystems (see, for example, MA 2005 or TEEB 2009). Economic analysis is an increasing feature of such undertakings and has prompted a rapidly expanding literature regarding the implementation of such analyses (see, for example, Bockstael et al. 2000; Balmford et al. 2002; de Groot et al. 2002; Howarth and Farber 2002; Heal et al. 2005; Barbier 2007; Boyd and Banzhaf 2007; Wallace 2007; Fisher and Turner 2008; Fisher et al. 2008; Mäler et al. 2008; Tschirhart 2009; Liu et al. 2010; Turner et al. 2010). It is the intention of the present paper to contribute to this literature in a number of ways. In particular we draw upon this preceding literature to propose a general framework and nomenclature for integrating economic analyses within ecosystem service assessments. Given the inherently interdisciplinary nature of such undertakings, we review some of the fundamental principles of economic analysis so as to introduce these to a natural science audience. At the same time we attempt to address certain key challenges which economists will have to face in order to adequately represent the complex nature of ecosystem service provision within economic analyses.

This paper has a direct empirical context as it provides much of the economic methodology underpinning the ongoing UK National Ecosystem Assessment (UK NEA). This exercise, coordinated by UNEP-WCMC, is a direct successor to the UN Millennium Ecosystem Assessment (MA 2005), adapted for the specific context of the UK and taking on a number of conceptual and scientific advances which have arisen since 2005. The MA conceptual framework linked primary 'supporting services' (e.g. soil formation) to 'provisioning' (e.g. food production), 'regulating' (e.g. climate) and 'cultural' (e.g. recreation) services. Its findings not only demonstrated the importance of ecosystem services to human wellbeing, but also showed that at global scales, many key services are being degraded and used unsustainably. The MA challenge was taken up by the UK House of Commons Environmental Audit Committee (2007) which recommended that, 'ultimately the Government should conduct a full MA-type assessment for the UK to enable the identification and development of effective policy responses to ecosystem service degradation'. Throughout this paper we illustrate the principles put forward by reference to the empirical approach adopted by the UK NEA. ${ }^{1}$

${ }^{1}$ For further details see http://uknea.unep-wcmc.org/. 
This is not a conventional economics journal paper. Rather it is intended as a means of introducing both economists and non-economists (and in particular natural scientists) to the UK NEA and through that to the wider principles involved in the application of economic analysis techniques to ecosystem service assessments. ${ }^{2}$ As such there are certain sections which review basic economic principles. We hope that the regular audience of this journal will tolerate this and find something of interest in the application of such techniques to the issue of ecosystem services.

Ecosystem service assessments and accompanying economic analyses can be roughly divided into two types. ${ }^{3}$ 'Sustainability analyses' are typically focused upon changes occurring up to the present day and involve assessing whether or not the observed development path of an economy has been progressively running down the natural asset base which underpins its viability. Such analyses provide important early warning signals for non-sustainable growth patterns (see for example, MA 2005 and TEEB 2009). However, once such warnings have been raised 'programme evaluation' analyses provide forward-looking, policy relevant assessments and comparisons of available alternative future development strategies. Such analyses are typically implemented through assessments of one or more future scenarios, the drivers of which include forecasts of environmental change, trends in domestic and world markets and potential (and possibly dynamically compensating) policy shifts. The UK NEA undertakes both forms of analysis, encompassing both a sustainability analysis of historic trends from the middle of the last century to the present day, as well as programme evaluations of different, alternative futures from the present until 2060 as captured in a series of scenario analyses. Given the prior literature on sustainability evaluations, the present paper focuses upon the forward looking programme evaluation element of the UK NEA and in particular the economic analyses to be conducted as part of this.

True to the economics roots of this paper we start by making a number of assumptions. However, we subsequently relax these to arrive at what we hope is a generally applicable approach to undertaking economic analyses for policy orientated, forward looking, ecosystem assessments of alternative scenarios.

Our initial assumptions hold constant two complicating factors; the passage of time and the sustainability of stocks of ecosystem assets. We neutralise the former issue by initially focussing upon a given scenario operating in a single period across which we assume individuals are indifferent as to when flows are received. ${ }^{4}$ Considering the latter issue and noting that ecosystem services are flows generated by stocks of ecosystem assets ${ }^{5}$ (e.g. the flow of trees for timber is generated by the stock of global forests), we further simplify by initially assuming that the rate at which ecosystem services are extracted is sustainable in that it does not reduce stocks over the assessment period (e.g. harvesting of timber stays within the range of natural regeneration). We relax both assumptions subsequently, but with these in place we now consider how one might conduct an economic analysis of ecosystem service flows across the period.

We start by discussing the overall conceptual framework of our approach and developing an accompanying terminology. We use this to consider the web of natural world relations underpinning each ecosystem service and acknowledge the role which human and manufactured capital play in combining with such services in the production of welfare bearing goods (e.g. trees are an insufficient input to generate timber which also requires human skills

\footnotetext{
2 We are grateful to the Guest Editors for the invitation to submit such an unconventional paper.

3 We are grateful to Sir Partha Dasgupta for highlighting this distinction.

4 Whether such a period actually exists we do not debate as we relax this assumption subsequently.

5 We are grateful to Karl-Göran Mäler for his advice and invaluable comments regarding this issue.
} 
and technology). ${ }^{6}$ We then consider methods for isolating the ecosystem service element within the production of such goods before considering the various methods used to value ecosystem services. These principles are put into practice through a related series of illustrations considering the issue of land use. These examples also serve to underline the need to ensure that economic analyses recognise the inherently spatial nature of most ecosystem services. This discussion is also used to relax our single period assumption. By allowing the benefits and costs of ecosystem services to occur across multiple periods we highlight the treatment of time within economics through the process of discounting. Finally we relax our sustainability assumption and consider cases where the 'harvesting' of ecosystem service flows may lead to the long term depletion of natural assets. We conclude our discussions by considering alternative approaches to dealing with such problems.

\section{Conceptual Framework and Terminology}

The Millennium Ecosystem Assessment defines ecosystem services as "the benefits people obtain from ecosystems" (MA 2005; p. 53). Fisher and Turner (2008) expand on this definition to propose that "ecosystem services are the aspects of ecosystems utilized (actively or passively) to produce human well-being" (p. 2051). Both definitions clarify the anthropocentric focus of the ecosystem service concept. ${ }^{7}$ While a wider understanding of environmental processes may be a necessary part of any ecosystem assessment, it is the role of the natural world in delivering human wellbeing which is central to assessments of ecosystem services. It is this human focus that necessitates the integration of economic analysis within such assessments so that we can quantify and value ecosystem services ensuring that their importance and worth can be incorporated within decision making.

As mentioned previously, the level of ecosystem service 'harvested' within any given period can be thought of as a 'flow' extracted from an underlying 'stock' of ecosystem asset (Barbier 2009; Mäler et al. 2009). ${ }^{8}$ Just as with a stock of financial wealth in a bank, the withdrawal rate can either be sustainable (say an amount which is less than or equal to the real value of interest paid in that period) or unsustainable (an amount which, if maintained, will eventually deplete the real value of the asset to levels which then reduce the available flow of income). ${ }^{9}$ However, we initially consider just a single period throughout which the

\footnotetext{
6 Changes in scenario are reflected by alterations in the levels of services and other inputs resulting in altered outputs of goods.

7 This also alerts us to the potential conflicts which may arise when decision making is based on preferences. Some people may consider certain species' repulsive or dislike entire ecosystems. In a recent economic valuation study, respondents gave positive values for reductions in the extent of coastal mudflats (Bateman et al. 2009b); a finding which reflected the negative visual amenity of such areas as perceived by many people. Of course these need to be set against the biodiversity habitat, coastal defence, pollution regulation and other benefits such areas provide (Barbier 1994). Nevertheless decision making through economic valuation is a reflection of human preferences. This is, with some caveats (certain of which we discuss subsequently), in line with a democratic ethos but as such exposes assessments to the tyranny of the majority. At the same time it shows that pressure groups can attempt to influence the outcome of economic analyses of ecosystem services by changing peoples' preferences.

8 Having a larger stock of ecological assets might mean that more services will be enjoyed although, as Barbier et al. (2008) and Boyd and Krupnick (2009) note, the relationship may be non-linear and lagged.

9 Note that economists will sometimes refer to flows as income and to stocks as wealth, the true intergenerational value of which is referred to as 'inclusive' or 'comprehensive' wealth (Arrow et al. 2007; Dasgupta 2009; Mäler 2008; Mäler et al. 2009) as discussed subsequently.
} 
rate of flow extraction is sustainable in that it does not deplete stocks (an assumption which we relax subsequently). ${ }^{10}$

From an economic perspective then, ecosystem services are those contributions of the natural world which generate goods which people value. However, this statement requires some qualification. First, by 'goods' we mean any item or construct that increases human welfare. ${ }^{11}$ This includes physical products (e.g. the role of ecosystem services in the production of food) and less tangible goods (e.g. detoxification services). It also includes items which generate use values (such as those just mentioned) and non-use goods which are valued purely for their continued existence (e.g. some unobserved biodiversity). Second, although the valuation of such goods relies upon standard economic theory (Daily 1997; MA 2003; Pagiola et al. 2004; Heal et al. 2005; Barbier 2007, 2009; Sukhdev 2008), these values might not be perfectly or even partially reflected in market prices and therefore require the application of non-market valuation techniques (subsequently we briefly discuss goods which may not be amenable to such methods). This process of uncovering the true value of goods and using this to ensure decisions contribute to improving human welfare is the defining rationale for economic analysis $^{12}$ and can result in major gains in wellbeing even when (as currently assumed) the use of ecological assets is sustainable; it obviously takes on an even more crucial role in cases (as considered subsequently) of unsustainable ecological exploitation.

As noted in our introduction, the focus of this paper is to consider the role of economic analysis for ecosystem service assessments within the context of supporting future orientated policy decision making at a project or programme level. This emphasis imposes some structure upon both the economic and natural science elements of ecosystem service assessments. In particular, Fisher et al. (2008) note the potential for double counting errors if an attempt is made to directly value those ecological processes (e.g. weathering, soil formation, nutrient cycling, etc.) which support multiple ecosystem services. The concern here is that if we value both these primary ecological processes (functions) and what we can term the 'final ecosystem services' which directly generate wellbeing or directly contribute to the production of goods, then we are liable to overestimate the total values generated. An obvious concern in adopting such an approach is that an over-concentration on final ecosystem services and their use and non-use to humans may place underlying ecological assets at risk (Gren et al. 1994; Turner et al. 1999) thereby risking over exploitation and system change or collapse. This has to be guarded against by imposing the constraint that ecosystem assets are not run down to unsustainable levels; an issue we are currently assuming away and which we return to focus upon subsequently.

\footnotetext{
10 Of course some resources are physically non-renewable, for example coal stocks. This highlights the fact that we are looking at the maintenance of services rather than the physical constitution of any given asset. So we might run down the stock of coal yet maintain the service of energy provision by increasing stocks of alternative energy resources. However, other resources, such as global oxygen stocks, are effectively non-renewable and non-substitutable (Ayres 2007).

11 This definition is therefore a deliberate conflation of the three forms of ecosystem service benefit defined by Daily (1997) and Barbier (2007), namely: (i) "goods" (e.g., products obtained from ecosystems, such as resource harvests, water and genetic material), (ii) "services" (e.g., recreational and tourism benefits or certain ecological regulatory functions, such as water purification, climate regulation, and erosion control), and (iii) cultural benefits (e.g., spiritual and religious beliefs, heritage values).

12 This is very different from accountancy with which economics is sometimes erroneously confused. The accountant focuses upon the market price of goods (which for many environmental goods is zero), while the economist is interested in their true value.
} 
We can now define a set of terms for subsequent use and which are intended to be intuitively accessible to both natural scientists and economists: ${ }^{13}$

- We place ecosystems in their particular spatially and temporally defined context. This requires us to know the relevant boundary conditions (e.g. elevation, slope, climate, etc) which define this context at any given location.

- Given these boundary conditions we can observe the pertaining ecosystem structure (e.g. animals, birds, plants and their connections, etc.) and processes (e.g. nutrient cycling etc).

- 'Ecological assets' are the stocks of potential services which the ecosystem, conditioned by structure and processes, might provide. In economic terms we can think of these as the 'wealth' of the ecosystem.

- We use the term 'ecosystem services' to refer to the flow of services (outcomes of structure and processes) provided by ecological assets in some assessment period.

- 'Final ecosystem services' are simply the last item in the chain of ecosystem functioning which inputs to the production of goods. They are the aspects of the natural environment which most directly affect human wellbeing during an assessment period and can also be thought of as the natural 'income' enjoyed during that time. The focus on the final item in the chain of ecosystem services is simply to avoid the double counting which would occur if we also included those more primary and intermediate supporting services. However, while a focus upon final ecosystem services significantly simplifies the economic valuation task, it is insufficient to ensure sustainability and we return to consider this latter problem later in this paper.

- 'Good' is the term we use for any object or construct which generates human wellbeing. ${ }^{14}$ This includes both physical and non-physical (pure experiential) objects. So a beautiful natural landscape generates amenity views which are a good to the outdoor walker as much as a piece of timber is a good to the home improver. As noted, some of these items come straight from the natural world without the intervention of humans; the visual amenity of the natural landscape being an example of this (here the final ecosystem service and the good are identical). In contrast other items (like our timber example) require some inputs of manufactured or other human capital.

- 'Benefit' is simply the change in human wellbeing generated by a good. Previous ecosystem service assessments have on occasion used the terms 'good' and 'benefit' synonymously. However, we draw a sharp distinction to highlight the fact that the same good can generate very different benefit values depending on its context (e.g. location) and timing of delivery. ${ }^{15}$ Note that some goods generate instrumental 'use value' (e.g. the timber example), while others deliver 'non-use value' (e.g. the knowledge that biodiversity is being conserved even if the person expressing the value does not observe the species concerned). These benefits include both use and non-use values.

\footnotetext{
13 We acknowledge that these terms differ from some of those which economists have used previously; see for example Heal et al. (2005).

${ }^{14}$ Note also that this definition of good embraces the economic definitions of both goods and economic services (the latter term including non-consumptive, experiential items). This is a deliberate simplification intended to enhance understanding between the natural and social sciences and avoid a double meaning of the word 'service' being used.

15 For example, considering the spatial context of a good, a woodland situated on the edge of a major city will generate much greater recreation benefits than a physically identical woodland situated in some remote area. Of course biodiversity might be inversely related to urban proximity. Analysing such trade-offs are the essence of environmental economics.
} 


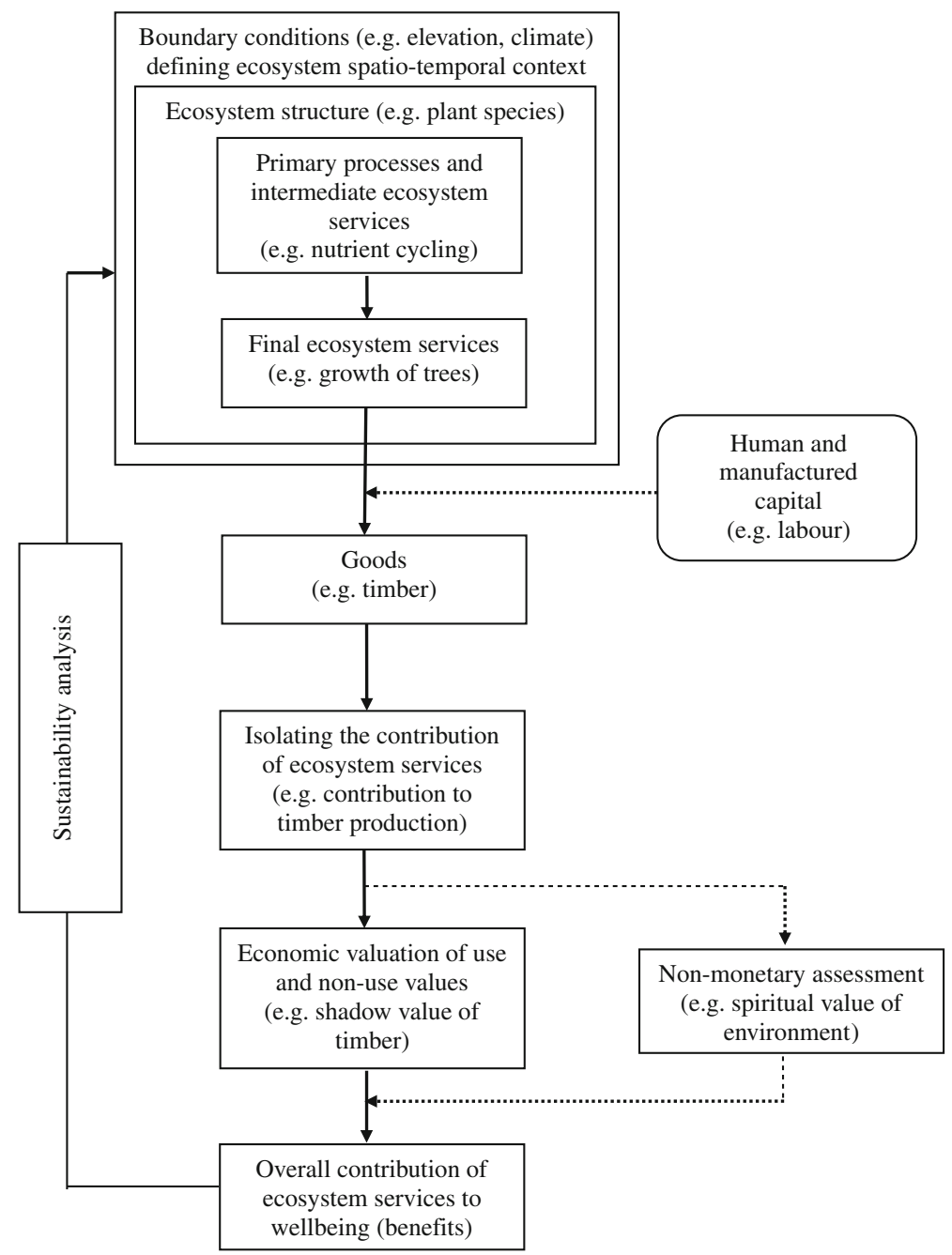

Fig. 1 Phases of a joint ecosystem assessment and economic analysis for a single scenario (examples given in parentheses). Notes Solid lines indicate relations which always apply while dotted lines indicate relations that may or may not apply, as determined on a case by case basis

With these definitions in hand we can now provide a schematic representation of the overall integration of economic analyses within ecosystem service assessments for any single given scenario, as illustrated in Fig. 1.

Figure 1 provides a route map for our subsequent discussions. Starting from the top, we see the initial flow from primary and intermediate through to final ecosystem services. In many, but not all, ${ }^{16}$ cases the latter services will then be augmented by human and manufactured capital inputs before generating welfare bearing goods. We then isolate the contribution of ecosystem services to the production of those goods as failing to do so negates the contribution of human and manufactured capital and so risks overstating the value of ecosystem services

16 Hence the use of dashed lines to indicate relations that may not necessarily apply. 
and undermining the credibility of such analyses. Once isolated, economic analyses seek to assess this value in monetary terms. While complex, this task permits the decision-maker to compare the value of ecosystem service benefits on an equal footing with the other goods (e.g. healthcare, education, etc.) which determine social wellbeing. However, as acknowledged in Fig. 1, at present not all of the benefits derived from ecosystem services are necessarily amenable to monetary valuation (e.g. environmentally related social norms; the spiritual value of the natural world; etc.). However, the drive of the UK NEA and the focus of this paper is to apply economic assessment as widely as possible and utilise alternative approaches ${ }^{17}$ only as necessary, feeding these appraisals into the final assessment of wellbeing as constraints upon, or consequences arising from, alternative decision strategies. For any given scenario the final stage of the analysis is to assess the sustainability of a situation in terms of the stock of underlying ecological assets. As mentioned, we currently assume this away and return to this vital issue in the latter part of this paper. Altering the trend, environmental or policy drivers which define a scenario will result in changes to ecosystem service and manufactured or human capital inputs which will in turn feed through to different outputs of goods and hence altered values.

\section{From Ecosystem Services to Welfare Bearing Goods: Scenario Analyses}

Figure 1 illustrates the distinction between supporting primary processes and the final ecosystem services which contribute directly to the production of goods. However, an assessment needs to address both primary processes and final ecosystem services, as the status of the former provide vital information for evaluating the sustainability of systems (currently assumed to be sustainable), while the latter is required for analysis of the economic value of service flows. Clearly accurate quantification of natural assets and services is a pre-requisite for any credible ecosystem assessment. In the case of the UK NEA, a team of over 160 eminent natural scientists were assembled to quantify the status of ecosystem processes, assets and final ecosystem services they generate across the UK. ${ }^{18}$ The natural science team was divided into two major groupings; those working to assess individual habitats (eight groups as follows: Mountains, moors and heathlands; Semi-natural grasslands; Enclosed farmland including arable and improved grasslands; Woodlands; Freshwater, wetlands and flood plains; Urban; Coastal margins; and the Marine environment) and those collating information across the former groups to asses trends and interactions in services (four groups as follows: Supporting services including primary and intermediate services; Provisioning services such as food, wood, etc.; Regulating services such as pollution assimilation, climate regulation, natural disease control, etc.; and Cultural services including those items to be quantified in non-monetary terms such as spiritual values, ecological education, etc.). In addition to these central groups a further team was assembled to ensure that the contribution of biodiversity

\footnotetext{
17 Some argue that such issues require alternatives to the individual centred approach of economics, favouring instead group approaches to assessment (Wilson and Howarth 2002; Spash 2008). More compatible with the approach of economic analysis is the recent rise in research into direct measures of subjective wellbeing and happiness (Kahneman et al. 1997; Layard 2005; Oswald and Wu 2010). Here researchers model individuals' self-rated happiness as a function of their socio-economic circumstances and prevailing environmental conditions (Welsch and Kuhling 2008), thus permitting estimation of an implicit trade-off between the two.

18 A substantial complication concerns international trade in ecosystem services (both imports and exports of ecosystem services and waste). While the UK NEA will conduct preliminary assessment of this trade the major focus is on domestically produced ecosystem services.
} 
Table 1 Final ecosystem services and corresponding goods: Examples from the UK NEA

\begin{tabular}{|c|c|}
\hline Final ecosystem service ${ }^{a}$ & Principal related goods \\
\hline $\begin{array}{l}\text { Production of crops, plants, livestock, fish, etc. } \\
\quad \text { (wild and domesticated) }^{\mathrm{b}}\end{array}$ & $\begin{array}{l}\text { Food, fibre, energy, genetic resources, industrial } \\
\text { inputs, fertiliser, avoidance of climate stress, } \\
\text { recreation and tourism, physical and mental } \\
\text { health, ecological knowledge, etc. }\end{array}$ \\
\hline Production of trees, standing vegetation and peat ${ }^{b}$ & $\begin{array}{l}\text { Timber, avoidance of climate stress, energy, } \\
\text { noise regulation, recreation and tourism, etc. }\end{array}$ \\
\hline $\begin{array}{l}\text { Production of wild species diversity including } \\
\text { microbes } \mathrm{b}, \mathrm{c}\end{array}$ & $\begin{array}{l}\text { Natural medicine, disease and pest control, } \\
\text { genetic resources, wild food, bioprospecting, } \\
\text { recreation and tourism, physical health, } \\
\text { ecological knowledge, etc. }\end{array}$ \\
\hline Production of water quantity $\mathrm{b}, \mathrm{c}$ & $\begin{array}{l}\text { Potable water, Industrial use of water, flood } \\
\text { protection, energy, recreation and tourism, } \\
\text { physical health, ecological knowledge, etc. }\end{array}$ \\
\hline Regulation of the climate ${ }^{c}$ & $\begin{array}{l}\text { Avoidance of climate stress, physical and mental } \\
\text { health, ecological knowledge, etc. }\end{array}$ \\
\hline $\begin{array}{l}\text { Regulation of hazards; related vegetation and } \\
\text { other habitats }{ }^{c}\end{array}$ & $\begin{array}{l}\text { Coastal protection, erosion protection, flood } \\
\text { protection, avoidance of climate stress, } \\
\text { physical and mental health, ecological } \\
\text { knowledge, etc. }\end{array}$ \\
\hline Breakdown and detoxification of waste ${ }^{c}$ & $\begin{array}{l}\text { Pollution control, waste removal, waste } \\
\text { degradation, physical and mental health, } \\
\text { ecological knowledge, etc. }\end{array}$ \\
\hline Purification processes ${ }^{\mathrm{c}}$ & $\begin{array}{l}\text { Clean air, clean water, clean soils, physical } \\
\text { health, ecological knowledge, etc. }\end{array}$ \\
\hline $\begin{array}{l}\text { Generation and maintenance of meaningful } \\
\text { places; socially valued landscapes and } \\
\text { waterscapes }^{\mathrm{d}}\end{array}$ & $\begin{array}{l}\text { Recreation and tourism, physical and mental } \\
\text { health, ecological knowledge, etc. }\end{array}$ \\
\hline
\end{tabular}

\footnotetext{
a As noted previously, other inputs (e.g. manufactured capital) may in some occasions be required to combine with final ecosystem services in the production of goods. Relating the final ecosystem services to the MA (2005) nomenclature:

b 'Provisioning' services;

c 'Regulating' services;

d 'Cultural' services. 'Supporting' services relate to primary ecological services
}

to all groups of services was assessed. ${ }^{19}$ Further groups were added to allow analyses to be aggregated to specific spatial decision making levels, notably for each of the individual countries subsumed within the UK.

The economics team was organised to complement the natural science structure of the UK NEA with subgroups assigned to work with each of the habitat, service and biodiversity teams. An early task involving both the economists and natural scientists was to define the list of final ecosystem services and corresponding goods around which the economic analysis would focus. This clarified the distinction between final ecosystem service (e.g. trees) and economic good (e.g. timber). Table 1 provides an overview of some of the final ecosystem services and corresponding goods being considered under the UK NEA. ${ }^{20}$

Mapping and quantifying the linkages between primary processes, intermediate and final ecosystems services through to welfare bearing goods is one of the most fundamentally

19 The special focus accorded to biodiversity reflects a concern that, because of its highly interactive and co-dependent role across multiple habitat groups, it might be overlooked if only dealt with at the habitat level.

20 This classification appears similar and is conceptually compatible to that given by Haines-Young et al. (2009) in their recent report to the European Environment Agency on this issue. 
important undertaking for an ecosystem assessment. Analysis of historic trends then permits a sustainability analysis of development to date. However, policy making requires future orientated assessments conducted through analyses of scenarios. The crucial outset point for any scenario analysis is the baseline from which all alternative scenarios are to be judged. A number of options exist for defining such baselines, including the present day position, extension of current trends or a Bayesian approach. Whichever approach is preferred, an obvious baseline would use prior trends and existing best estimates to construct the likely future path for ecosystem services taking into account three drivers: (i) available knowledge on environmental change (e.g. UK Climate Projections estimates of climate change), (ii) the likely path of market forces (e.g. OECD and FAO estimates of economic activity, commodity and fuel prices, etc.) and (iii) ongoing and planned policy initiatives (e.g. continued reform of the EU Common Agricultural Policy). The definition of alternative future scenarios has been a substantial focus of recent research (OST 1999, 2003; IPCC 2000; Environment Agency 2001; UKCIP 2001; Hulme et al. 2002; MA 2004; PMSU 2004; Pinnegar et al. 2006; Murphy et al. 2009; Foresight Foresight Land Use Futures Project 2010). However, like most ecosystem assessments, the UK NEA considers a number of alternatives reflecting multiple changes in the environmental, market and policy drivers outlined above. These reflect not only the best estimates underpinning the baseline, but variations due to uncertainty and a variety of policy response options. Scenarios can also be constructed to reflect aspirational objectives through which inspection of the changes required to achieve such ends can be undertaken.

\section{Isolating the Ecosystem Service Contribution to the Production of Welfare Bearing Goods}

As discussed in greater detail subsequently, the value of ecosystem services is generally assessed by looking at the welfare generated by the goods produced using those services (whether they generate use and/or non-use values). However, this does not imply that we can attribute all of the value of those goods to ecosystem services. To show this consider a situation in which a given ecosystem service input is lost. Outputs of associated goods may therefore reduce and in extreme cases fall to zero. However, even in the latter case we may well be in error if we assign all of the value of those goods to the ecosystem service. This is because those goods are often produced by combining ecosystem services with other resources such as manufactured or human capital. While the loss of ecosystem service inputs would almost inevitably lead to some net loss of value, ${ }^{21}$ this value loss is not total as there will be some reallocation of these other resources to different ends. Assigning all of a good's value to its ecosystem service input assigns a zero value to all other inputs and ignores the potential for reallocation of the latter inputs to other productive ends. Such error would overestimate the value of ecosystem services in a way that risks undermining the credibility of assessments and a return to the default position of ignoring ecosystem values.

So, before we jump to consider the value of ecosystem services, we first need to consider the role they play in the production of quantities of goods. To do this we also need to consider and control for all the other inputs which affect that production. There are a number of ways to undertake such an analysis, but one which illustrates the underlying principles is to consider a 'production function' such as the following: 22

21 Both because of the loss of the ecosystem service itself and because one might expect that the other resources being used had been so allocated because this was the best way in which they could be used.

22 For an introduction to production functions see Perman et al. (1996) and Chiang (1984). 


$$
q=q(m, n)
$$

where $q$ denotes the output of some good, $m$ is a vector of manufactured and human capital inputs (e.g. labour) and $n$ denotes a vector of natural capital inputs of which one is the ecosystem service we are focussing upon. There are a host of possible specifications of the production function (see Griffin et al. 1987) and the task of defining a given form typically involves considering both the empirical suitability of a form and how well it reflects reality. For the purposes of illustration we can consider the Cobb-Douglas (CD) production function (Chiang 1984) which has some properties likely to be reflected in ecosystem services. The CD function is as follows:

$$
q=m^{\alpha} n^{\beta}
$$

If there are multiple inputs involved in producing $q$ (say 1 to $M$ of the $m$ inputs and 1 to $N$ of the $n$ inputs) then the $\mathrm{CD}$ production function becomes:

$$
q=m_{1}^{\alpha_{1}} m_{2}^{\alpha_{2}}, \ldots, m_{M}^{\alpha_{M}} n_{1}^{\beta_{1}} n_{2}^{\beta_{2}}, \ldots, n_{N}^{\beta_{N}}
$$

The CD function has a useful property when we take natural logarithms that:

$$
\ln q=\alpha_{1} \ln m_{1}+\alpha_{2} \ln m_{2}+\cdots+\alpha_{M} \ln m_{M}+\beta_{1} \ln n_{1}+\beta_{2} \ln n_{2}+\cdots+\beta_{N} \ln n_{N}
$$

where the coefficients $\alpha_{1}, \alpha_{2}, \ldots, \alpha_{M}, \beta_{1}, \beta_{2}, \ldots, \beta_{N}$ are known as the 'elasticities' of production of $q$ of the respective inputs $m_{1}, m_{2}, \ldots, m_{M}, n_{1}, n_{2}, \ldots, n_{N}$. This means that, all else remaining equal, a one percent increase in input $n_{1}$ will lead to a $\beta_{1}$ percent increase in production of $q$. The value of these coefficients reflects available technology and will therefore change with technology but, broadly speaking, technical improvements will increase the value of the coefficients indicating that we obtain more output for a given unit of input.

The CD function (like most feasible production functions) exhibits the property that as we reduce the level of one input so we have to increase levels of one or more other inputs in order to maintain the level of output of $q$. The rate at which one input can be substituted for another while keeping output constant is known as the elasticity of technical substitution which we denote as $\sigma$. If $\sigma=0$ then any reduction in an input will directly reduce output and cannot be offset by increases in other inputs. ${ }^{23}$ This describes a 'strong sustainability' (Pearce et al. 1989) situation where the level of ecosystem service inputs from natural capital must be maintained to ensure long-term sustainability. At the other extreme, when $\sigma=\infty$ then the impact on $q$ of an $x$ percent decrease in one input can always be exactly offset by a $y$ percent increase in another. Such as situation conforms to a 'weak sustainability' (ibid.) worldview in which there are no 'critical' inputs without which production is impossible and sustainability is ensured simply by ensuring that the sum of natural and manufactured capital is non-declining, rather than by needing to maintain any particular (e.g. natural) capital type.

Typically $\sigma$ is neither zero nor infinite, lying instead between these extremes. ${ }^{24}$ Here reductions in say natural capital inputs can be substituted for by increases in manufactured capital but in a manner such that, as the availability of $n$ declines, so progressively greater quantities of $m$ have to be employed to maintain output of $q$. Now where all inputs are priced

\footnotetext{
23 An example is the Leontief production function where inputs can only be combined in fixed proportions such that an increase in just one input has no impact on production, while a decrease in one input cannot be offset by increasing another.

24 The CD function provides such an example for which $\sigma=1$. One of the less plausible aspects of the CD function is that it indicates that if and only if any input fell to zero then $q$ would also cease. In reality such states might be unlikely to occur due to the very large levels of other inputs required to maintain $q$ as any given input is run down toward zero.
} 
at their true value then the progressive nature of this substitution relationship provides a break on the over-exploitation of any given resource. However, when some inputs (such as $n$ ) do not have market prices or those prices underestimate their true value then producers have an incentive to continually substitute $n$ for $m$ and drive down their costs irrespective of the loss of $n$ (and associated true value) this will incur. This incentive persists even in areas of the production function where large inputs of $n$ are needed to substitute for further reductions in $m$. Such incentives underpin the growing drive to value natural asset inputs as reflected in analyses such as the UK NEA.

Real world production relationships are often more complex than the CD case and may involve a plethora of inputs exhibiting a variety of output and substitution relationships within a single function (we consider an example subsequently). Despite this, for the reasons discussed previously, it is important to identify the contribution of ecosystem services to goods separately from those obtained from manufactured and other human capital. However, even when this is achieved we still face the tricky issue of valuing these ecosystem service inputs; an issue to which we now turn.

\section{Valuing Ecosystem Services}

Perhaps the source of most confusion in practical decision making concerning the environment are two commonplace terms which most people use interchangeably: 'value' and 'price'. ${ }^{25}$ That they are not in fact equivalent is easy to demonstrate. Consider a walk in a local park. The market price of such recreation is likely to be zero as there are no entrance fees and anyone can simply walk in. However, the very fact that people do indeed spend their valuable time in parks shows that this is not a zero value good. It is clear to see that 'value' and 'price' are not necessarily the same thing. In fact price of some unit of consumption is simply that portion of its value which is realised within the market place. Now in some cases price may be a perfectly acceptable approximation to value, particularly where all the inputs to the production of a good are privately owned, that good is produced in a competitive market ${ }^{26}$ and where there is not large scale intervention by governments or other authorities. ${ }^{27}$ Indeed even when these latter distortions do arise economists can often adjust for their influence. However, as the park recreation example shows, market price can in some cases be a poor approximation of value, indeed this divergence can often be substantial and is a characteristic of many of the goods produced by the natural environment.

Economists have developed a variety of methods to for estimating the value of goods whose market prices are either imperfect reflections of that value or non-existent. These methods are discussed in detail through a variety of reviews and guidelines see, for example, Barbier (2007), Bateman (2007), Bateman et al. (2002a), Champ et al. (2003), Freeman (2003), Hanley and Barbier (2009), Heal et al. (2005), Kanninen (2006) and Pagiola et al. (2004). This is a substantial literature and we are unable to provide a detailed assessment within the confines of the present paper. Accordingly we present only a brief summary and critique of the methods overviewed in Table 2 with the reader referred to the above literature for an in-depth consideration. Furthermore we emphasise that, within this section we retain

\footnotetext{
25 Another common and related confusion concerns the terms 'accountant' and 'economist'. Accountants are interested in market prices, whereas the true economist should be interested in values.

26 Typically, the less competitive a market the more any individual producer can exerting pressure upon price.

27 Interventions such as government subsidies or taxation can strongly distort prices away from their competitive market levels.
} 


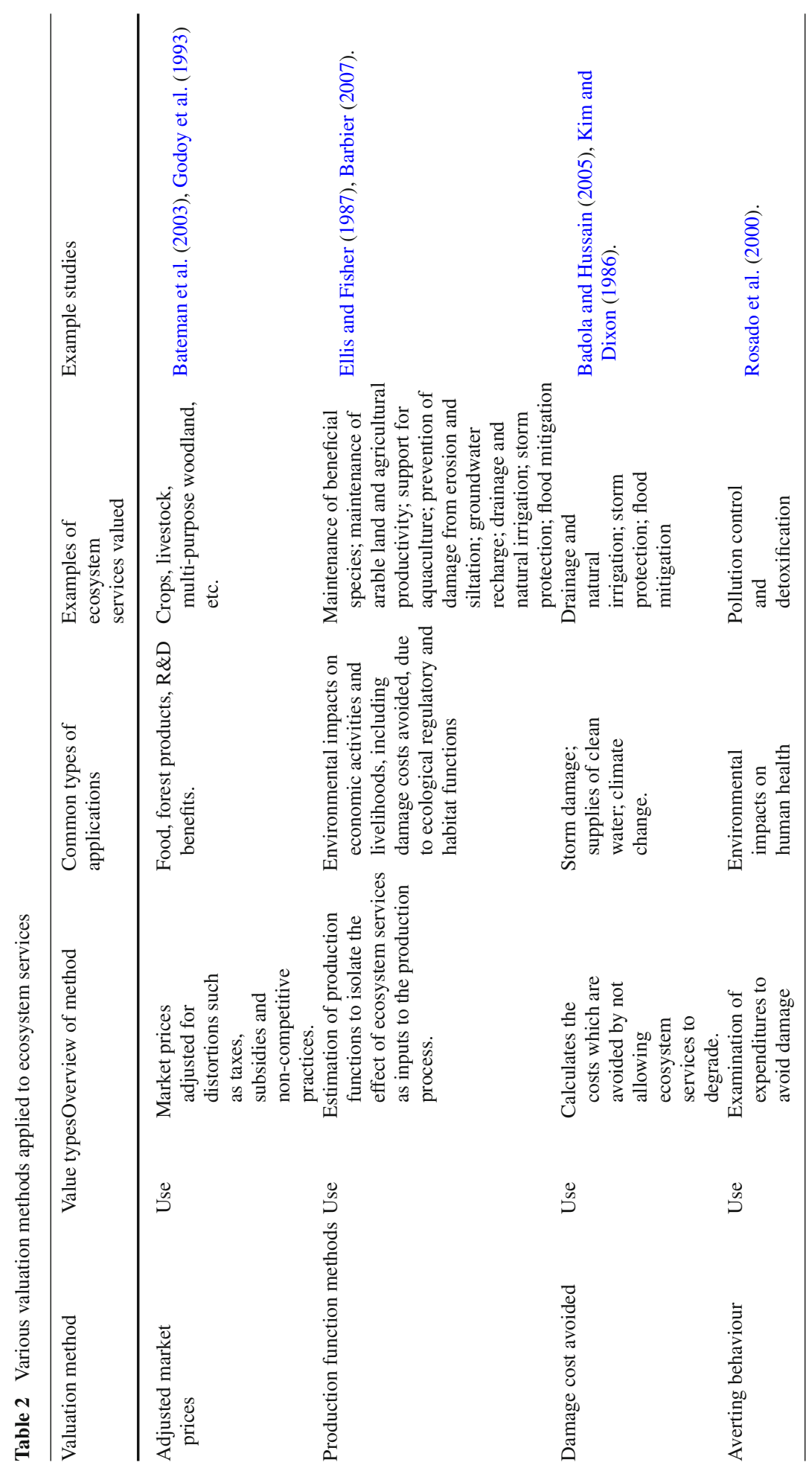




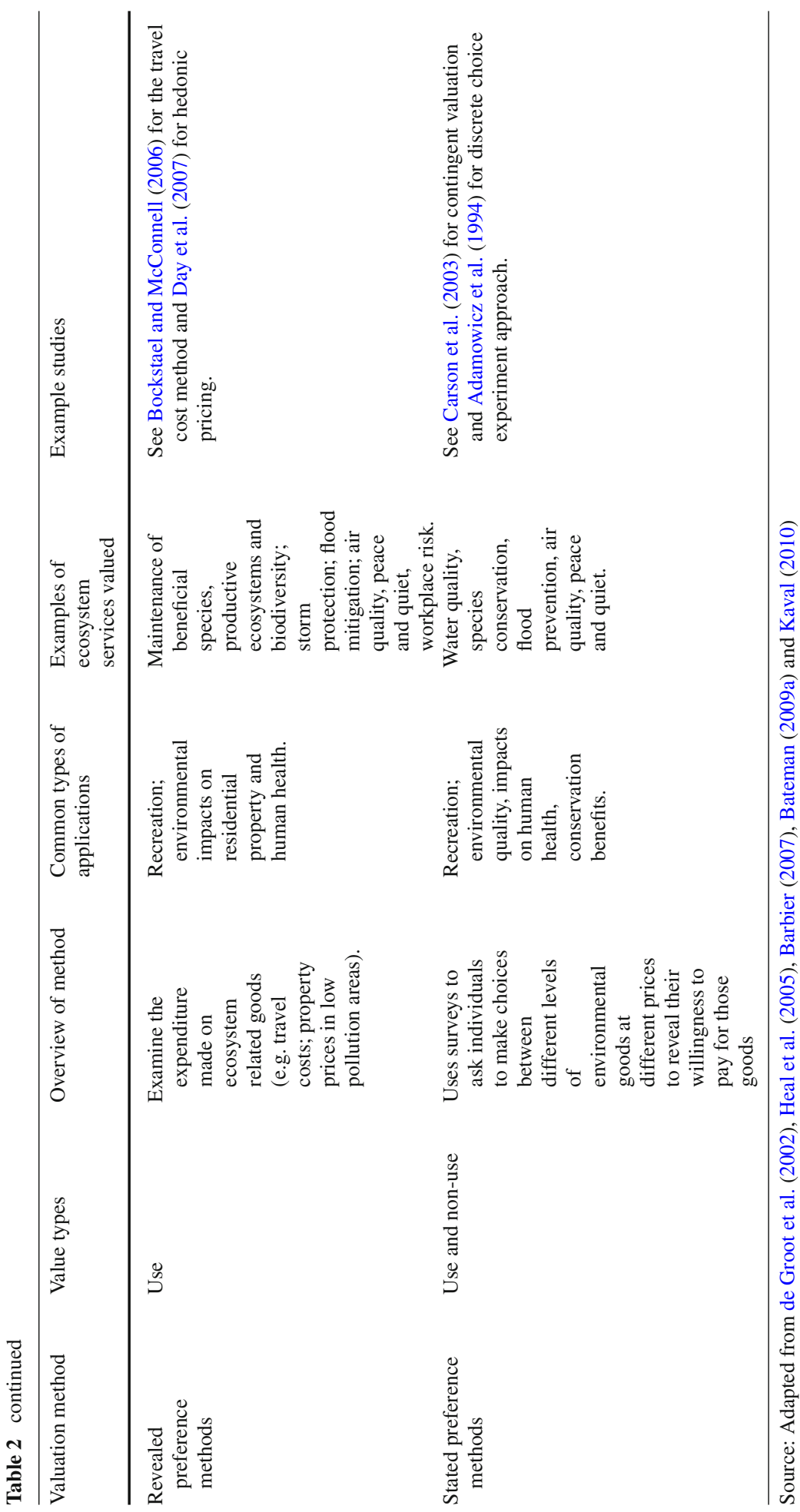


our focus on just the present period but note that true values can only be fully captured within a multi-period assessment to which we turn subsequently.

Considering Table 2, as noted, market prices can in some cases provide an acceptable starting point for valuation. ${ }^{28}$ However, adjustment should always be made to correct for market distortions such as taxes and subsidies (which are effectively merely transfers from one part of society to another) as well as for non-competitive practices (Freeman 1991; Nicholson et al. 2009; Dasgupta 2009). Related to this approach, is the factor input or production function method (see Barbier 2000, 2007; Freeman 2003 and Hanley and Barbier 2009). As discussed in the previous section, this examines the contribution of all of the inputs used to produce a good in terms of the value they add. ${ }^{29}$ This approach can be applied to a range of market (consumption) goods but has also been used for valuing regulatory and 'protection' goods (examples of the latter including flooding and extreme weather protection) ${ }^{30}$ All of these approaches infer values by examining linkages with (adjusted) market priced goods. This tactic is also used in the examination of potential value losses in terms of avoided damage costs or behaviour and expenditure intended to avert such damages. ${ }^{31}$ However, we have excluded the use of restoration or replacement costs as a proxy for the value of ecosystem services. Although there are a few interesting examples of such studies, ${ }^{32}$ many economists consider that such methods should be used with caution (Barbier 1994, 2007; Ellis and Fisher 1987; Freeman 2003; Heal 2000) due to the likelihood that restoration or replacement costs will bear little resemblance to the values they approximate.

The methods described above might appear straightforward. However, this is somewhat deceptive. Recall that the task of the economist is to estimate the value of goods in terms of the welfare they generate, rather than simply their market price. As mentioned it is only under a set of fairly restrictive assumptions that we can take market price as a direct estimate of value (recall the park recreation example) and the adjustment process from the former to the latter is far from straightforward. However, even this route becomes impassable for goods which are devoid of market prices such as outdoor, open-access recreation, or peace and quiet. Revealed preference methods provide an approach to the valuation of goods such as these where an individual can only enjoy some non-market environmental good through the consumption of some market priced private good. Here economists make use of the "weak complementarity' concept introduced by Mäler (1974) to examine how much individuals are prepared to spend on the private good in order to enjoy the environmental good, thereby revealing the value of the latter. A number of variants of the revealed preference approach exist. For example, the travel cost method examines the expenditure and time that individuals are prepared to give up to visit environmental recreation areas. Similarly, the hedonic property price method examines the premium which people are prepared to pay in order to purchase houses in areas of higher environmental quality (e.g. quieter, less polluted neighbourhoods).

\footnotetext{
28 The use of market prices within a green accounting approach to assessing ecosystem services is discussed by Cairns (2002).

29 Examples of production function based valuations of ecosystem services include: multi-purpose woodlands (Barbier 2003; Boscolo and Vincent 2003; Nalle et al. 2004); marine nutrient balance (Gren et al. 1997; Smith 2007; Knowler et al. 2001; Knowler and Barbier 2005), pollination (Ricketts et al. 2004); power generation (Considine and Larson 2006); fisheries (Rodwell et al. 2002; Mardle et al. 2004; Sumaila 2002; Barbier 2003, 2007); watershed protection (Kaiser and Roumasset 2002; Hansen and Hellerstein 2007).

30 Examples include the storm protection values of mangroves in Thailand (Barbier 2007) and hurricanes along the US Atlantic and Gulf coasts Costanza et al. (2008).

31 Note that the averting behaviour method could also be viewed as a variant of the revealed preference approach discussed subsequently.

32 See, for example, the study of the New York City drinking water source in the Catskills Mountains discussed by Chichilnisky and Heal (1998).
} 
By controlling for other determinants (e.g. the number of bedrooms in a property) such purchases reveal the values people hold for these environmental goods. ${ }^{33}$ However, while these methods have been widely applied, they have various drawbacks and limitations. They often require a number of assumptions to hold ${ }^{34}$ as well as copious amounts of data and intensive statistical analysis.

While revealed preference techniques tend to be applicable to a relatively narrow range of goods, stated preference approaches such as contingent valuation and discrete choice experiment methods should, in theory, be applicable to a wide range of ecosystem service goods ${ }^{35}$ and typically they are the only option available for estimating non-use values. ${ }^{36}$ Such methods are defensible in cases where respondents have clear prior preferences for the goods in question or can discover economically consistent preferences within the course of the survey exercise. Where this is not the case then elicited values do not provide a sound basis for decision analysis. Such problems are most likely to occur for goods with which individuals have little experience and poor understanding (Bateman et al. 2008a,b, 2010a). ${ }^{37}$ Therefore while stated preferences may provide sound valuations for high experience, use value goods, the further we move to consider indirect use and pure non-use values, the more likely we are to encounter problems.

While a number of solutions have been proposed for the problem of valuing low experience, non-use goods, ${ }^{38}$ we have to consider those cases where such values cannot be established to any acceptable degree of validity. The question of what should be done in such cases has generated much debate, but one approach is the adoption of ecological standards (see subsequent discussion of 'safe minimum standards') to ensure the sustainability of resources (such as the continued existence of species) which are not amenable to valuation (Farmer and Randall

\footnotetext{
33 Notice that the hedonic property price approach examines the value of a flow of services as capitalised within house prices. A related approach is to model the relationship between the price of land and its attributes. Examples of such 'Ricardian' analyses include Fezzi and Bateman (2010), Mendelsohn et al. (1994), Schenkler et al. (2005) and Seo et al. (2009).

34 See, for example Randall (1994) on the travel cost method and Day et al. (2007) on the hedonic pricing method.

35 The stated preference literature is vast but for a few examples focussed upon ecosystem services Naylor and Drew (1998), Banzhaf et al. (2006), Carlsson et al. (2003), Othman et al. (2004), Hanley et al. (2003), Hearne and Salinas (2002), Huybers and Bennett (2003), Mansfield et al. (2008), Naidoo and Wiktor (2005), Rolfe et al. (2000).

36 Notice that we deliberately eschew the term 'intrinsic value'. The word 'intrinsic' is defined by the Merriam-Webster dictionary as "belonging to the essential nature or constitution of a thing". Therefore the intrinsic value of say an endangered British bird such as the bittern (Eaton et al. 2009) belongs to the bittern and cannot be accurately defined by another entity such as a human. Of course humans can and do hold values for bitterns. These can include the use value held by bird-watchers and the non-use values which a wider group hold for the continued existence of the bittern as a species. However, these are anthropocentric rather than intrinsic values. To claim that we have any knowledge of intrinsic values lends a confusing and erroneous air of moral justification to assessments. Although some would argue for notions of human assigned intrinsic values (e.g. Hargrove 1992), from an economic perspective much so called 'intrinsic' values would instead be reclassified as non-use existence values. Arguably true intrinsic values (e.g. the value of the bittern to the bittern) could be protected by a property rights approach which makes it illegal to harm the species concerned. However, such rules are likely only to be enacted when they are actually supported by anthropocentric non-use values.

37 A related problem is where variants of the stated preference approach provide survey respondents with heuristic cues regarding response strategies (Bateman et al. 2009a).

38 One approach is to use more naturalistic approaches to the description of low experience goods; for example using virtual reality software to convey images of landscape goods (Bateman et al. 2009b). Others have proposed the use of intensive valuation workshops (Christie et al. 2006). However, such techniques are prone to reliance upon small, unrepresentative samples which, after such intensive experiences cannot be taken as reflecting general preferences.
} 
1998). This would not negate the need for economic analysis which would still play an important role in the identification of cost-effective approaches to ensuring the maintenance or the provision ecologically sustainable levels. ${ }^{39}$ A related strategy, the implementation of offsetting compensatory projects validated for their ecological suitability (Federal Register 1995), would also generally require such cost-effectiveness analysis. ${ }^{40}$

Despite the various caveats outlined above, probably the most serious problems facing the effective and robust valuation of ecosystem services are gaps in our understanding of the underpinning science relating those services ${ }^{41}$ to the production of goods and the paucity of valuation studies and available data regarding the values of these goods. While interdisciplinary efforts between natural scientists and economists are crucial to addressing the former problem, the lack of valuation studies has lead to the ongoing development of methods to transfer values from existing 'source' studies to desired 'policy' applications.

The value transfer literature ${ }^{42}$ embraces a number of approaches. The simplest technique is to search for a prior source valuation study which addresses a good and context which approximates that of the policy application and apply the value from the former to the latter. $^{43}$ This simple approach, often referred to as mean value transfer (because typically it is the average value which is transferred) is defensible provided that source and policy good and context are highly similar. However, the limitations of source valuation studies mean that this often not be the case. In such cases one option is to attempt to adjust the source values by incorporating differences between the source and policy contexts (e.g. differences in good characteristics, changes in valuing populations and their characteristics, different use costs or substitute/complement availability, etc.). Although some studies have attempted to affect such adjustments through expert assessment, a quantified adjustment process is clearly preferable if executed carefully. ${ }^{44}$ One variant of the latter approach is to conduct a meta-analysis of results from previous studies, relating values to the characteristics of those studies and the goods and contexts valued. Such an analysis typically yields a regression model linking values to the characteristics captured in the available source data. The analyst can then apply the characteristics of some policy case to this model to estimate the relevant value. So, for example, Brander et al. (2006) conduct a meta-analysis of over 190 wetland valuation studies, providing 215 value observations. Significant determinants of value include, amongst

\footnotetext{
39 For an example of a cost-effective approach to species preservation see Bateman et al. (2009c) and contrast this to the highly variable stated preference values for these projects given in Bateman et al. (2010a).

40 An exception being cases where there is only one option available for delivering sustainability, in which case that option becomes a fixed constraint on any development policy (Barbier et al. 1990).

41 Two problems are particularly highlighted: (i) the availability of quantified data on changes in the provision of services over time and space under different scenarios; (ii) quantified understanding of the interactions between ecosystems and their services, particularly under novel general stressors such as global climate change. These issues will require concerted action and high degrees of collaboration between the natural and social sciences.

42 Examples of value transfers (sometimes called benefit transfers although this is confusing as these techniques can also be applied to costs) and related meta-analyses for environmental goods include Barton 2002; Bateman et al. 2009d, 2010b; Bateman and Jones 2003; Bergland et al. 1995; Brouwer 2000; Brouwer and Spanninks 1999; Brouwer et al. 1999; Carson et al. 1996; Desvousges et al. 1992; Downing and Ozuna 1996; Johnstone and Duke 2009; Johnston et al. 2005, 2006; Leon-Gonzalez and Scarpa 2008; Lindhjem and Navrud 2008; Moeltner et al. 2007; Muthke and Holm-Mueller 2004; Navrud and Ready 2007; Ready et al. 2004; TEEB 2009; Zandersen et al. 2007.

43 Transfer databases such as The Environmental Valuation Reference Inventory (EVRI, available at www. evri.ca) have been developed to assist the search process for such applications.

44 This caveat is important. Poor or incomplete quantitative adjustments can generate greater errors than simple mean value transfers (see demonstration by Brouwer and Bateman 2005). However, accurate, quantified and full adjustments outperform simple mean transfers (Bateman et al. 2009d).
} 
others, wetland size, the ecosystem services and goods provided and population characteristics related to size and income. ${ }^{45}$ By quantifying these variables for some policy application, analysts can use the parameters of the meta-analysis model to estimate values for the policy case.

An alternative and potentially more flexible and sophisticated approach to adjusting from source to policy values is to estimate and transfer a spatially explicit value function. This approach can be applied to the estimation not only of unit values but also to predicting the quantity change to which they are applied. For example, Bateman et al. (2010c) collect data on the location and frequency of trips to river sites across a large area of north-eastern England (chosen because of its diversity of river qualities and locations, and the variability of population density and socioeconomic characteristics). By interviewing a large sample of households and applying a variant of the travel cost model ${ }^{46}$ the analysts estimate a model which predicts how the number and value of visits responds to a variety of spatially variable factors. These include both the location and quality of rivers, but also of substitute and complementary attractions and the density and socioeconomic characteristics of the population. Once such data is gathered its analysis yields estimates of the parameters describing the relationship between each of the above factors and the number and value of visits. Transferral of such functions is then relatively straightforward as secondary data sources can provide information on all of the predictors in the model for any area in the country (e.g. all locations and distances are provided by analysis of map data while official environment agencies hold data on river quality and census bodies store population characteristics). ${ }^{47}$ Extracting such data for areas of policy interest and applying these to the estimated parameters yields the desired value and demand estimates. ${ }^{48}$

Whatever method is chosen for valuing preferences for an environmental non-market good, it must be capable of capturing the complex contextual aspects of such values. One of the most complex yet important aspects of such values is that even when, as we continue to assume, overall stocks are at or above sustainable levels the size of that stock may affect the value of changes in flows. This can be illustrated in part through reference to the highly cited study by Costanza et al. (1997) which attempted to provide value estimates for the total stock of all ecosystem services globally. While their paper very substantially raised awareness of the application of economics to ecosystem assessments, particularly within the natural science community, the focus upon valuing total stocks has been criticised on a number of grounds (e.g. Heal et al. 2005). ${ }^{49}$ In particular, very few policy decisions relate to total losses of ecosystem services. Instead policy changes require an understanding of the value of changing a single unit of a stock. Economists refer to this as the 'marginal' value of the ecosystem service in question. Of course if the value of a marginal unit is constant then it is straightforward to go from valuing a single unit to valuing whatever number of units

\footnotetext{
45 A complicating factor in such meta-analyses is the significant effect exerted upon values by the choice of valuation methodology in the source studies (see also Bateman and Jones 2003).

46 Specifically the travel cost random utility model (RUM) (see Bockstael and McConnell 2006; Champ et al. 2003; Haab and McConnell 2002).

47 As discussed in Bateman et al. (2002b, 2006) and Troy and Wilson (2006), a geographical information system (GIS) greatly eases the computational tasks underpinning related operations such as distance calculations and can readily be adapted to undertake the value transfer exercise.

48 While the development of these various value transfer methods has allowed researchers to increase the usefulness of the existing literature (TEEB 2009; Bateman et al. 2010b), there remains a significant information gap with respect to source valuations which will only be addressed through a concerted and efficiently designed programme of research (Carpenter et al. 2009; Nicholson et al. 2009).

49 Note that while they do not provide solutions to these problems, Costanza et al. (1997) are well aware of these issues and raise these within the discussion of their findings.
} 

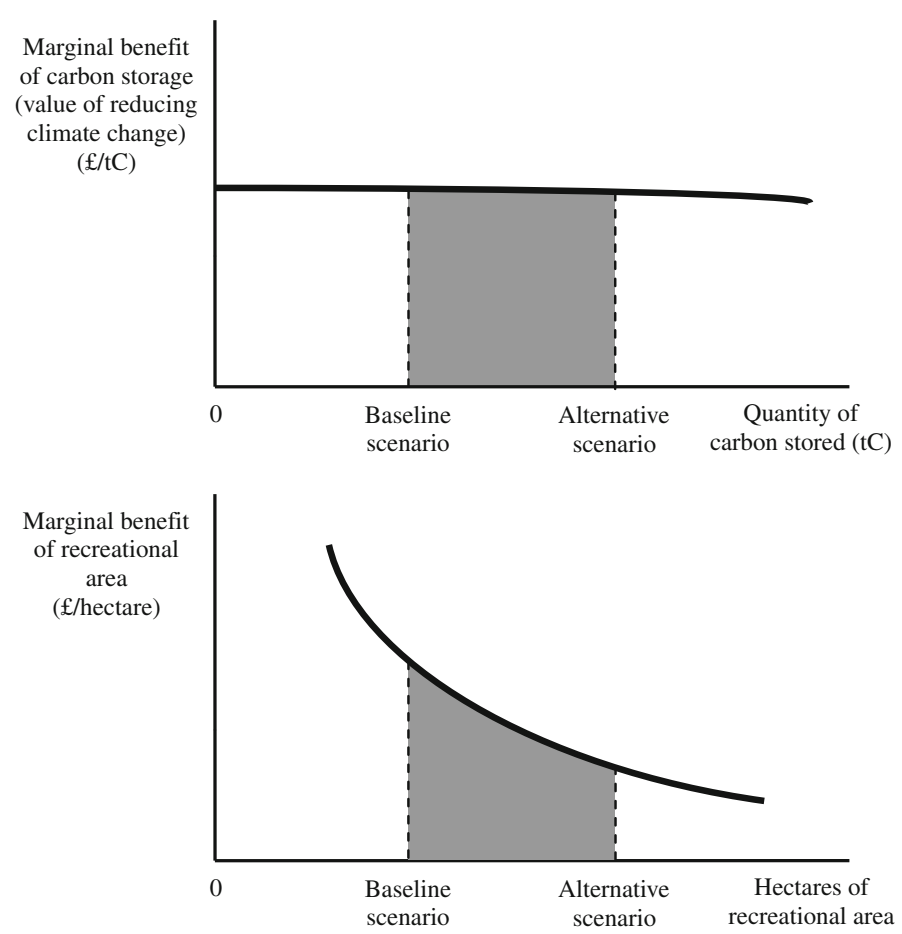

Fig. 2 Marginal benefit curves for two goods

a given policy will create or destroy. However, an interesting phenomena is that for many goods and services, marginal values will change with the total size of the stock, even when the overall stock level is above sustainable levels (as presently assumed).

Figure 2 illustrates the relevant point here by contrasting the two cases: the first concerning the marginal benefit (i.e. the per unit value) of reducing climate change by increasing carbon storage; the second showing the marginal benefit of increasing the area of recreational greenspace. In both cases we postulate a situation where there is a policy which changes land use so as to increase the provision of both carbon storage and land for recreation (e.g. through the creation of wetland areas suitable for peat accumulation and hence carbon storage as well as recreational visits).

The upper panel of Fig. 2 shows a (virtually) constant level for the marginal benefit of carbon storage throughout the range of feasible projects confined to some area of the UK. This reflects the simple fact that, using existing technologies whereby the bulk of carbon storage is held in living biomass and soils, the UK is simply not big enough to capture sufficient carbon to significantly reduce the problem of climate change to the level where the marginal benefits of further carbon capture change. Only if carbon sequestration were to be undertaken on a truly global scale would it begin to significantly affect the potential for damaging climate change and hence reduce the marginal value of further carbon capture. Here then, the total benefit value of the envisioned provision change is estimated by multiplying the (constant) marginal benefit of carbon capture by the increase in provision between the baseline and alternative scenario.

A more complex situation is shown in the lower panel which concerns increases in the area of recreational land. While initial provision of such area may be highly valued, once 
that is provided, further (marginal) units of land generate progressively lower increases in recreational value. The Brander et al. (2006) meta-analysis of valuation studies mentioned previously provides a good example of such a case with per hectare values diminishing as the overall size of a wetland area increases. This pattern of diminishing marginal values is a characteristic of many goods (even carbon capture would exhibit such a pattern once climate change began to be significantly ameliorated). ${ }^{50}$

The lower panel of Fig. 2 also illustrates why it may be unwise to attempt to estimate the total value of ecosystem stocks rather than the value of specified changes. A total value would be given by integrating the marginal value curve back to a level of zero provision. However, such a situation (e.g. the disappearance of all recreational land) may be highly unlikely to occur. Equally importantly it moves the calculation through areas of the marginal benefits curve which are entirely unsupported by data. Extrapolation out of the range of existing data is likely to generate unrealistically high values. One common alternative to this approach is to use the current level of marginal benefits and hold this constant for the calculation of total values. However, just as the former approach is likely to generate over-estimates of value, this latter method ignores the shape of the marginal benefits curve and is liable to lead to underestimates of total value. Both options are unattractive and unnecessary. The focus upon changes in value between feasible scenarios is much more relevant for decision purposes. Accordingly this is the approach adopted for the UK NEA which argues that, for the valuation of any good we require:

(i) Understanding of the change in provision of the good under consideration (i.e. the change in the number of units being provided) given changes in the environment, policies and societal trends;

(ii) A robust and reliable estimate of the marginal (i.e. per unit) benefit value; and

(iii) Knowledge of how (ii) might alter as (i) changes.

The major challenge facing these requirements is the present state of knowledge regarding all of these issues. In the absence of full information (which will often be the case), both ecosystem assessments and accompanying economic analyses need to explicitly acknowledge uncertainties in their work and convey these to decision makers in clear terms. This in itself poses a substantial challenge which goes beyond the remit of this present paper.

\section{Illustrations: Land Use Change}

In this section we illustrate the various principles laid out previously, highlighting the issues of identifying the contribution of certain final ecosystem services to the production of both market and (subsequently) non-market goods and their economic valuation. We also use this example to illustrate the importance of incorporating the spatial complexity of the environment into analyses, ${ }^{51}$ including the multiple values that can be generated by a given change and the conflict of values generated by mutually exclusive goods.

\footnotetext{
50 The two panels of Fig. 2 also reflect the role of location in determining values. While the benefits of storing a tonne of carbon are spatially unconstrained (all individuals gain from this good), the benefits of increasing the size of a given recreational area are highly spatially confined, being disproportionately captured by those who live near to the site. This of course means that the spatial location of recreational sites near to population centres can substantially increase their value. Bateman et al. (2006) discusses the concept of 'distance decay' in such values. Note also that this raises the possibility of localised losses of stocks occurring even when regional, national or global stocks are maintained. This is likely to generate high spatial specificity in marginal values.

51 For further discussion of both spatial and temporal complexity see Rodriguez et al. (2006).
} 
Table 3 Land use share equations parameter estimates for cereals

\begin{tabular}{|c|c|}
\hline Variable & Estimated coefficient \\
\hline Price $_{\text {cereals }}$ & $0.134 * * *$ \\
\hline Price $_{\text {fertilizer }}$ & $-0.111 * * *$ \\
\hline Set aside rate & $-0.425 * * * *$ \\
\hline Environmentally sensitive area (ESA) share of grid square & $-0.033 * * * *$ \\
\hline Park share of grid square & $-0.019 * * *$ \\
\hline Urban share of grid square & $-0.028 * *$ \\
\hline Share of agricultural land with slope higher than $6^{\circ}$ & $-0.087 * * *$ \\
\hline Coastal (dummy) & -0.357 \\
\hline Mean elevation & $14.170 * * * *$ \\
\hline Mean elevation squared & $6.333 * * *$ \\
\hline Autumn machinery working days & $4.174 * * * *$ \\
\hline Autumn machinery working days squared & $-1.283 * * *$ \\
\hline Mean potential evapotranspiration & $6.727 * * *$ \\
\hline Mean potential evapotranspiration squared & $-2.773 * *$ \\
\hline Median duration of field capacity & $-4.794 *$ \\
\hline Median duration of field capacity squared & $16.670 * * *$ \\
\hline Total number of degree days in the growing season & $-4.228 * * *$ \\
\hline Total number of degree days in the growing season squared & $2.571 * *$ \\
\hline Average annual rainfall & -3.726 \\
\hline Average annual rainfall squared & -1.269 \\
\hline Trend & 0.015 \\
\hline Constant & $38.040 * * * *$ \\
\hline
\end{tabular}

Notes: Due to the limitations of space the equations relative the other land uses and the parameters corresponding to the interactions of the environmental factors are not reported in the Table, but are available on Fezzi and Bateman (2009). * t-stat $>2 ; * * \mathrm{t}-\mathrm{stat}>3 ; * * * \mathrm{t}-\mathrm{stat}>4 ; * * * * \mathrm{t}-\mathrm{stat}>10$

In order to provide a common empirical theme to this illustration we consider the wideranging issue of land use change as this combines all of the topics covered so far in this paper. Considering first farmed land, we apply the structural model of agricultural land use developed by Fezzi and Bateman (2009). This model draws upon highly disaggregated $2 \mathrm{~km}$ resolution data for the entire area of England and Wales over a period spanning more than 40 years. The model shows how profit maximising land use alters in response to changes in the physical environment (e.g. climate change), market conditions (e.g. prices and costs) and policy (e.g. revisions of the EU Common Agricultural Policy). In estimating this model, rather than adopt a relatively inflexible function form such as a Cobb-Douglas a more sophisticated specification $^{52}$ was employed to yield land use share estimates for all major agricultural arable and pastoral activities. Table 3 reports just one of these; a model of the share of each $2 \mathrm{~km}$ square of England and Wales which is devoted to cereals.

The model reported in Table 3 is, in effect, a spatially explicit transfer function, allowing us to predict the amount of land devoted to cereals in any location for which we have the

52 A normalized quadratic function was adopted as this has been widely applied in agricultural economics for modelling joint (in input) multi-output production processes (Moore et al. 1994; Oude and Peerlings 1996; Guyomard et al. 1996; Arnade and Kelch 2007). 
predictors shown (which, for the UK, are held for all areas of the country). The model also allows us to isolate the contributions of a variety of ecosystem services to the production of the good in question. This is shown by the estimated parameters corresponding to each of the ecosystem services contributing to the decision to produce cereals. Furthermore we can use these parameters to investigate the impacts of a change in any or all of these ecosystems services and/or the other determinants. This change might be derived from some external model forecasting future trends or from an explicit scenario analysis reflecting expert estimates and/or policy aspirations.

We can illustrate the use of such models by varying just one of these ecosystem services; the climate. We might obtain predictions of future climate from some existing model (e.g. the IPCC model summarised in Pachauri and Reisinger 2007). However, for purely illustrative purposes we can adopt a simple climate change scenario, holding constant all other land use determinants (prices, policy, urbanization, other ecosystem services, etc.) and increasing daily average temperature by $1^{\circ} \mathrm{C}$; an increase which is expected to occur in the UK by about 2030 (Murphy et al. 2009). ${ }^{53}$ This in turn alters the total number of degree days in the growing season captured in our model. Applied across all of the major agricultural land uses embraced in the model we find a highly heterogeneous pattern of response across different areas of England and Wales. This is hardly surprising given that, despite the relatively modest size of this area it embraces a great diversity of farming conditions and agricultural activities. The resultant spatial pattern of changes in the production of cereals is illustrated in the left hand panel of Fig. 3. This shows the area of cereals increasing in the northern parts of the country, where the warmer temperature will be beneficial to yield, and decreasing in the south where it is substituted for by other activities.

While climate change induced shifts in land use pattern are clearly important (informing us about impacts upon food production, landscape changes and a host of related impacts), from the perspective of economic analysis we need to monetise these changes. The right hand panel of Fig. 3 takes into account all of the shifts in land use driven by this simple climate change (i.e. including the substitution across all of the different agricultural activities) and provides a simple market price assessment of the financial impact ${ }^{54}$ of this scenario.

The analyses of Fig. 3 are useful in that they demonstrate the principles of isolating the contribution of a given ecosystem service (here climate) within the production of goods. They also amply demonstrate the importance of incorporating spatial complexity within such analyses; as can be seen the impacts of climate change vary substantially (and from negative to positive) across England and Wales. However, this analysis does not go far enough in that it needs to move from market price to assess its true social value as well as considering the wider impacts induced by land use change. In order to illustrate this we present an analysis of a part of the above area, focussing upon the country of Wales, and draw on the work of Bateman et al. (2002a, 2003) and Bateman (2009b).

Figure 4 presents, in the left hand panel, the market price of Welsh agricultural output ${ }^{55}$ and, in the right hand panel, its economic value. Both have been estimated by transferring a spatially explicit model as discussed previously. Results from this exercise show the

\footnotetext{
53 The simple scenario used in the present paper is purely for illustrative purposes and we ignore issues such as monthly variation in the rate of climate change, precipitation impacts and linked environmental changes (e.g. in evapotranspiration rate, etc.). Other work by the authors relaxes these assumptions and addresses the projections given in work undertaken by the UK Climate Projections project (Murphy et al. 2009).

54 This is here assessed using the commonly adopted measure of Farm Gross Margin (FGM) which is defined as the difference between revenues from agricultural activities and associated variable costs (FBU 2009; Defra 2009). The present illustration uses FGM figures for 2004.

55 The figures actually present results for the dairy sector. Other sectors are presented in Bateman et al. (2003).
} 


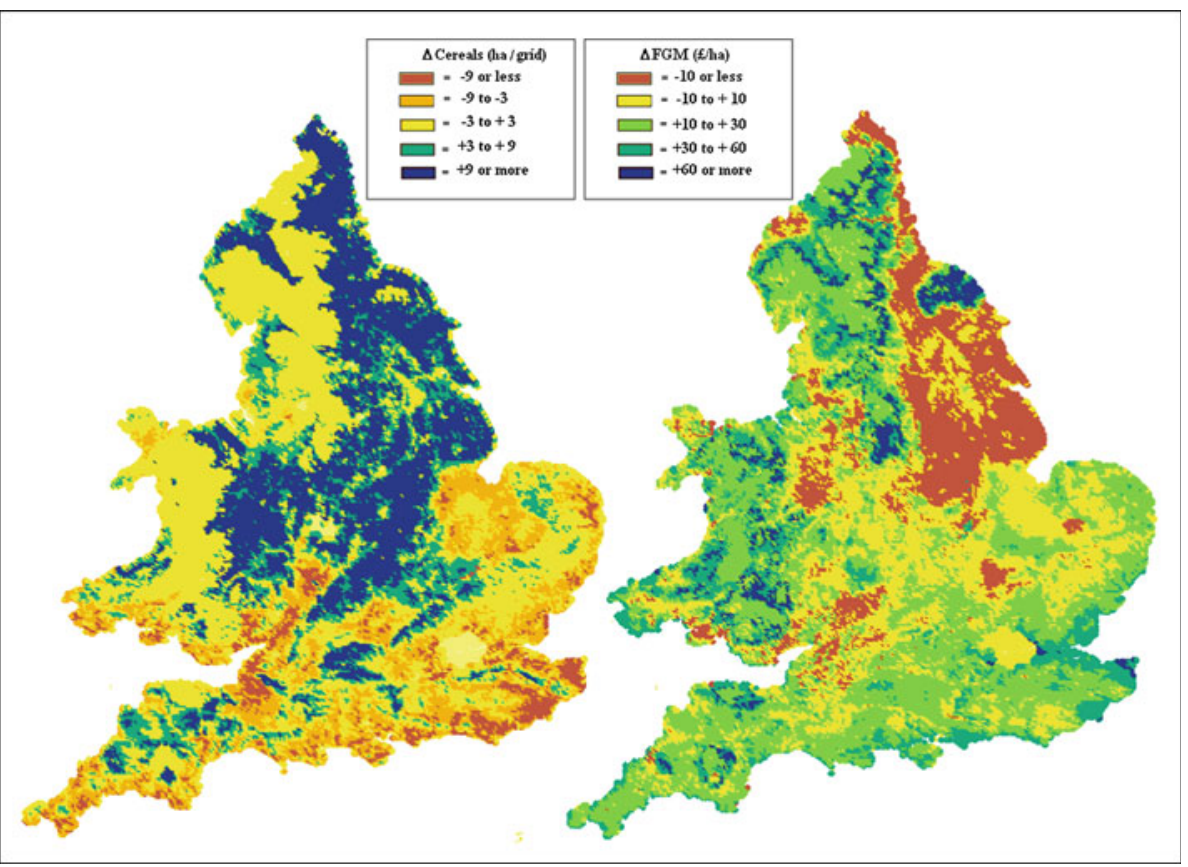

Fig. 3 Change in cereals (left hand panel) and market price assessment (right hand panel) under a simple climate change scenario

importance of spatial factors in determining values, with these being greatest in lowland coastal and eastern areas and lowest along the mountain chain which runs from north to south through central Wales. As can be seen, in this case, true values are below market prices because the latter are inflated by a series of subsidies and market interventions. This illustrates an important point that while economic values are often above market prices (due to the latter ignoring the elements of value that bypass the market), this relationship can be reversed, most noticeably when (as here) governments intervene to distort markets and raise the price of goods so as to increase their production.

While the valuation exercise illustrated in Fig. 4 is helpful, it is insufficient to guide land use decision making, most noticeably because it ignores 'opportunity costs'; the value which could be generated by alternative use of this land. Within the predominantly rural area of Wales one obvious alternative use is as multipurpose woodland. This would generate both market priced outputs, such as timber, and a variety of non-market values, of which we will just consider carbon storage and open-access recreation as illustrations. ${ }^{56}$

In assessing the quantitative change in provision which an alteration in land use from agriculture to multi-purpose woodland would induce, we employ spatially explicit transferable production functions similar to those discussed with respect to agriculture in our prior cereals example. In the case of timber such value functions take into account a host of spatially explicit data such as soil type, temperature, rainfall, topographic shelter, aspect, etc.

\footnotetext{
56 Conversion from agriculture to woodland increases carbon storage in living biomass and in virtually all soils except peatlands where tree planting causes peats to dry out and emit carbon; similarly in the UK most state forestry is open-access and hence has higher recreational value than enclosed farmland. Other social benefits of afforestation not considered in this illustration include water quantity and quality regulation and the provision of biodiversity habitat.
} 


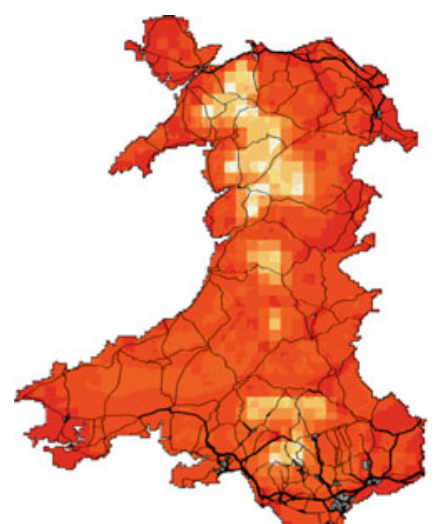

f/ha/year

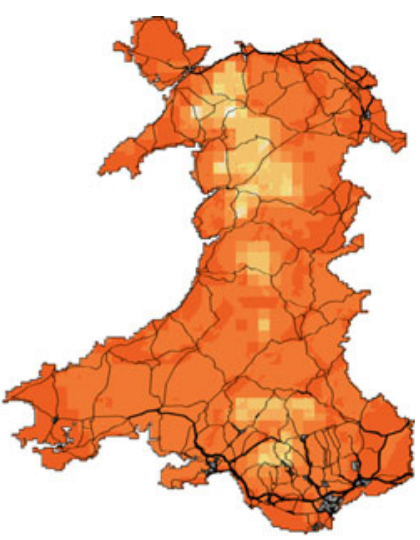

400 to 499

500 to 599

$>=600$

Urban

Main Roads

$\triangle$ Motorway

$\triangle$ Dual Carriageway

$\triangle$ Single Carriageway

200 to 299

300 to 399

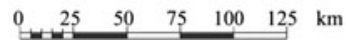

Fig. 4 Agricultural production expressed via its market price (left hand panel) and economic value (right hand panel), the latter adjusting for subsidies, market distortions, etc. Source Adapted from Bateman et al. (2003)

all of which can be derived from existing, high resolution national coverage databases. This allows us to estimate tree growth and timber production for different species and management regimes under baseline or alternative scenarios. Net carbon storage can then be modelled with respect to the growth of biomass, the storage or emission of carbon from different soils and the emission of carbon from felling and products (see Bateman et al. 2003 for details).

In attempting to value items such as timber production and carbon storage (and indeed all others being considered here) we now have to relax our focus upon a single period as it is obvious that these processes can take many years to develop yielding a flow of benefits (and costs) occurring at different points in time. ${ }^{57}$ Bringing together both the present and future allows us to expand and complete the economic concept of value. Returning to the banking analogy referred to early in this paper, the economic perspective argues that the value of some stock of wealth should be measured by assessing the present day worth of all the future flows of income which that wealth is expected to generate. Economic analysis achieves this by the process of discounting; a procedure which reflects the general preference for benefits which occur in the shorter rather than longer term. We consider the issue of discounting in a little more detail subsequently but the important issue for the current illustration is that it converts a series of future benefit flows into a single value measured in present day terms.

57 For detailed description of these analyses see Bateman et al. (2003). The timber valuation analysis takes into account subsidies and other market distortions. Both this and the carbon valuation take into account forecast changes in the real value of these goods (discussed in the sustainability section of this paper), while the carbon analysis considers carbon storage in above ground, species-specific biomass and its post-felling emission profile (adjusted for species and end-uses) as well as carbon flux within soils as a result of land use change. 


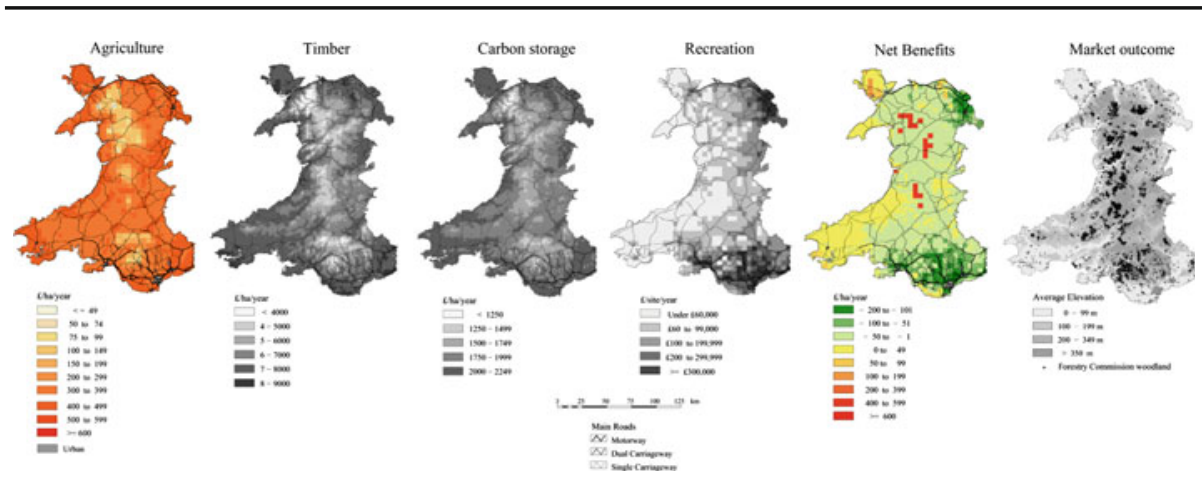

Fig. 5 Shadow values for various land use benefits. Sources Adapted from Bateman et al. (2002b, 2003) and Bateman (2009b). Values shown as annual equivalents, the discounted sum of which is the shadow value

This is known as the 'shadow value' of these income flows; a term which applies just as well to the benefits arising from ecosystem services. ${ }^{58}$

So, if we were undertaking an economic analysis of the timber benefits of a woodland we might assess its stock size in hectares and its flows of timber in cubic metres. However, to assess its shadow value (in pounds) we consider the present value of those future flows of timber. Of course we would typically want to consider all benefits, not just timber, and would apply the shadow value approach to each of these benefits. ${ }^{59}$ Figure 5 attempts to illustrate such an analysis through a series of maps, all but the last of which details the shadow value of the various benefit streams which arise from the land use decision under consideration. ${ }^{60}$ The first map relates to current agricultural land use. The next three maps (given in greyscale to highlight their common origin) illustrate respectively the timber, carbon storage and recreation values which would arise from changing land use into multipurpose woodland. ${ }^{61}$ The fifth map details the shadow value of the net benefits arising from subtracting the sum of woodland values from the agriculture value. Here the green areas indicate locations where woodland provides a higher shadow value than agriculture while yellow and red areas indicate locations where agriculture provides the highest values. It is interesting to note that the areas which generate the highest shadow values from conversion into woodland are in the northeast and south-east, a result which reflects the high populations in these areas and consequent elevated recreation values arising from afforestation. In contrast the most negative shadow values from such conversion are shown by the red areas corresponding to upland peats where afforestation causes major losses of soil carbon. The geographic distribution of net benefit

\footnotetext{
58 I am particularly indebted to Daan van Soest for comments regarding this issue.

59 Subsequently we discuss how values may change when stocks approach unsustainable levels. However, even above those levels some individuals may have preferences and hence values regarding a few stocks such as the existence values associated with populations of some species.

60 For ease of comparison each value has actually been calculated as an annual equivalent, the discounted sum of which is the shadow value. Therefore the shadow agricultural values given as the first map in Fig. 5 are virtually identical to those shown in the right hand panel of Fig. 4. For details see Bateman et al. (2003).

61 Each of these maps shows the change in value which this benefit stream generates. For the timber and recreation case this is a change from a zero prior value. However, for the carbon storage case this derives from the difference in storage generated by woodland as opposed to agriculture. The recreation analysis shown uses a transferable trip generation function to estimate the number of visits which would occur if a forest was created in a given location and a separate meta-analysis to estimate per-visit values (with aggregate values being given by multiplying per-visit values by the estimated number of visits). For a superior RUM approach to travel cost analysis see Herriges et al. (2004), Egan and Herriges (2006) and Bateman et al. (2010c).
} 
shadow values is in sharp contrast with the actual distribution of forests as illustrated in the final map. The latter is driven by market forces alone and hence ignores the carbon storage and recreation values instead being driven solely by the market values of agriculture (the left hand panel of Fig. 4) and forestry (the timber values alone). Here agriculture dominates all lowland areas pushing forestry up the hill to low productivity areas where land prices are lower. ${ }^{62}$ This results in a distribution of woodland which is in marked contrast to its true shadow value; a finding which underlines the importance of using shadow values rather than market prices to lead decision making.

\section{Discounting}

Towards the end of our illustrative land use study we relaxed our single period assumption in favour of considering the value of ecosystem services across multiple periods through the process of discounting. Here the shadow value of each good is assessed as the discounted present value of the stream of net benefits which are expected to be received into the future. For example, considering the shadow value of carbon storage we multiply the quantity of storage delivered in each year from the present onwards (ideally we should not be limiting appraisals by any arbitrary date) by an estimate of the social cost of carbon (see, for a discussion, Tol 2005). ${ }^{63}$ These values are then discounted and summed back to the present day. The reason why this does not generate an infinite sum is that the discounting process progressively reduces the present day value of future costs and benefits with this reduction increasing in intensity the further into the future we go.

The discounting procedure is based upon both theoretical and empirical arguments that individuals have a preference for receiving benefits sooner rather than later. This means that shadow values encapsulate within them conceptions of the impact of changes in the stock of all assets (including natural assets) upon intergenerational wellbeing. However, both the form and rate of the discounting procedure are the subject of intense controversy. This is nowhere more evident than in the debate surrounding the recent Stern Review on the economics of climate change (Stern 2007). Subsequent argument has focused on the evidence that underpinned the central conclusion of the Review that the "the benefits of strong, early action far outweigh the economic costs of not acting" (p. vx). In particular, the focus of much of this discussion has been on the way in which this conclusion was driven by choices made in setting the social discount rate ${ }^{64}$ including all of the fundamental reasons for discounting: pure time preference, the utility value of future increments in consumption and the extent to which it can be assumed that future consumption will be higher than consumption today (see, for example, Nordhaus 2007; Weitzman 2007; Dasgupta 2007).

A critical element of this debate centred on whether, in selecting the social discount rate, a descriptive approach or a prescriptive approach should be used (Dietz et al. 2007), a distinction which also can be found in IPCC (1996). Put another way, should investments in natural assets be appraised respectively in the light of information about preferences for the future as revealed in actual economic decisions or is there room for the practitioner to make explicit

62 This includes pushing forestry onto peatlands resulting in some woodlands which are net contributors to global warming (Adger et al. 1992).

63 Note that it is perfectly feasible that the 'real' value of a tonne of stored carbon need not be constant in all years. If the level of atmospheric $\mathrm{CO}_{2}$ rises over time so the marginal damage of an additional unit of emissions is likely to rise and with it the value of avoiding that emission. 'Real' vales adjust for any intervening inflation. All cost-benefit analyses should be conducted using such real values.

64 This is the rate relevant for decisions made on behalf of and reflecting the wishes of society. It differs and is typically markedly lower than the market discount rate which reflects private investment decisions. 
moral judgments about intergenerational equity. Stern (2007) opts for the latter approach and, as a result, adopts a very low discount rate giving a relatively high weight to future costs and benefits. The substance of Nordhaus (2007) and Weitzman (2007) is that there is, on the face of it, very little evidence that this moral reasoning is reflected in people's actual behaviour and choices and, thus, the empirical evidence suggests that the pure rate of time preference should take a higher value. Resolving such debates is far from straightforward, however, and faces profound questions on which, to quote Beckerman and Hepburn (2007) “... reasonable minds may differ" (p. 198).

Interestingly, recent discussions surrounding discounting have also broken new ground with the growing recognition that some environmental problems such as climate change are truly 'non-marginal' in the sense that this problem could end up shifting the global development path, say with 'business as usual' emissions of greenhouse gases possibly leading to considerably lower future consumption levels than now (Weitzman 2007; Hoel and Sterner 2007). Indeed the corresponding notion that the socially appropriate discount rate for short term effects might differ from that relevant to long term impacts (such as climate change) has caught hold in practical guidance (see Treasury 2003 for example and for review, support and critique see Groom et al. (2005), Dietz and Hepburn (2010) and Dasgupta (2001) respectively).

\section{Sustainability}

Following our shift of focus from single to multi-period assessment, we can now relax our final assumption that underlying stocks of ecological assets are held at sustainable levels ${ }^{65}$ (or equivalently that the rate of extraction or 'harvesting' of ecosystem service flows is sustainable). ${ }^{66}$ This move from a sole focus on flows to also considering stock is analogous to moving from only thinking about expenditure to also considering the wealth which supports it. Accordingly the economic literature surrounding this issue develops the notion of "Comprehensive Wealth" which considers the ecological stocks from which all ecosystem service flows are generated (Dasgupta and Mäler 2000; Arrow et al. 2007; Mäler et al. 2008; Dasgupta 2009). Clearly any economic analysis of ecosystem services has to appraise the impact of potential stock depletions in order to assess the sustainability of given states. Most of the literature has focussed upon assessing historic development paths through adjustments of national income accounts (Bartelmus 2001, 2008; United Nations 2003; Hamilton and Ruta 2009), however, given the future orientated emphasis of the present paper we focus upon approaches appropriate for project appraisals of alternative options. Specifically we consider three potential strategies for incorporating sustainability concerns into such appraisals: (i) assessment of how future depletion of ecosystem stocks might increase the marginal shadow value of corresponding services; (ii) incorporation of the insurance value of maintaining

\footnotetext{
65 It is important to remember throughout the following discussion that the economic notion of sustainability is rooted in values rather than simply physical stocks. This means that judgements regarding intergenerational wellbeing (including those reflected within the discounting process) are relevant here (see, for example, Hamilton and Clemens 1999; Dasgupta and Mäler 2000; Hamilton and Withagen 2007; Mäler et al. 2009).

66 Recall our earlier note that it is not the physical constitution of these assets (e.g. coal stocks) which is the issue but rather the sustainability of the services they provide (e.g. energy). Some resources are inherently non-renewable and therefore all usage is depletive in nature. However, the proceeds of such use can be invested so as to maintain service levels (e.g. using oil-fuelled economic growth to develop renewable energy alternatives). A significant issue is that the costs associated with using different forms of service may differ substantially. For example extraction costs for crude oil are far lower than those from oil shale (Strahan 2009). This may in turn have implications for intergenerational wellbeing.
} 
ecosystem resilience and; (iii) the use of safe minimum standards as a means of preserving stocks of ecosystem assets.

\subsection{Increasing Future Marginal Shadow Values}

Discounting is the process of converting benefits and costs occurring at some future date into their present day value. We remove the impact of inflation from this procedure and deal with the real (inflation adjusted) values arising at different points in time. However, from the seminal work of Krutilla and Fisher (1974) we know that there is no reason to suppose that these real values will stay the same throughout time. One factor which might affect the future marginal shadow value of ecosystem service flows is a change in the ecosystem asset stock from which that flow derives. Even then such stock reductions will only affect future values if the asset is reduced below some critical threshold which affects the sustainability of those flows. So, for example, consider the case of quartz, which is one of the most abundant minerals on earth. It is a major source of silicon which in turn is a vital input to numerous goods ranging from glass to food additives through to optical fibres and nanotechnology devices. However, due to the abundance of its stocks, any feasible pattern of depletion will not change the future value of silicon. But this is not the case for the ultra-pure mineral quartz used for computer processor manufacture for which stocks are only found in a very few locations (such as the famous mines at Spruce Pine, North Carolina). Here stocks are finite and continued exploitation could feasibly deplete these to a 'threshold' level below which the flow of such ecosystem services becomes reduced. One would expect that this would begin to increase the marginal value of those flows. While this example concerns goods which are traded in markets, the same principles should apply to non-market environmental goods except that now these effects will not be reflected in market prices but should be incorporated within the marginal shadow values used for economic analyses of ecosystem services.

The particular path that future marginal shadow values might follow depends on a number of factors and there are complicated issues to resolve about the empirical relationship between asset stocks, the flow of services and the way in which these services are valued at different stock levels (Pascal et al. 2009). However, a general point worth making is that if it is difficult to replace these services (i.e. the natural asset is characterised by limited substitution possibilities), then the marginal shadow value of the service is likely to rise all the more rapidly as the asset is increasingly degraded or converted (see, for example, Gerlagh and van der Zwaan 2002). ${ }^{67}$ Hoel and Sterner (2007) and Sterner and Persson (2008) show how the marginal shadow value of a scarce environmental service might increase over time. ${ }^{68}$

\footnotetext{
67 Gerlagh and van der Zwaan (2002) look at the case where individuals have a very strong preference for natural assets rather than non-substitutability per se (i.e. quasi-lexicographic preferences; see Rosenberger et al. 2003). The implications of this assumption, however, are that liquidating a natural asset beyond some threshold plausibly lowers the maximum level that future wellbeing can take.

68 Hoel and Sterner (2007) use a constant elasticity of substitution (CES) system to describe how wellbeing derived from both 'environmental quality' and 'all other consumption goods' are substitutable for one another. As they show, this has implications for the way in which changes in the marginal shadow value of an ecosystem service are calculated. This change depends on the interaction of three elements. First, faster growth in other consumption will increase marginal shadow values (because people are generally wealthier and so will be willing to pay more for environmental quality). Secondly, if environmental quality is decreasing then this the increase in shadow values will be greater (reflecting the fact that this good is becoming scarcer). Lastly, a low elasticity of substitution implies a larger increase in the relative price of environmental quality because the wellbeing provided is not easily compensated for by increases in consumption of other goods. Sterner and Persson (2008) use this framework to show how estimates of future climate change damages are sensitive to changes in assumptions about substitutability.
} 


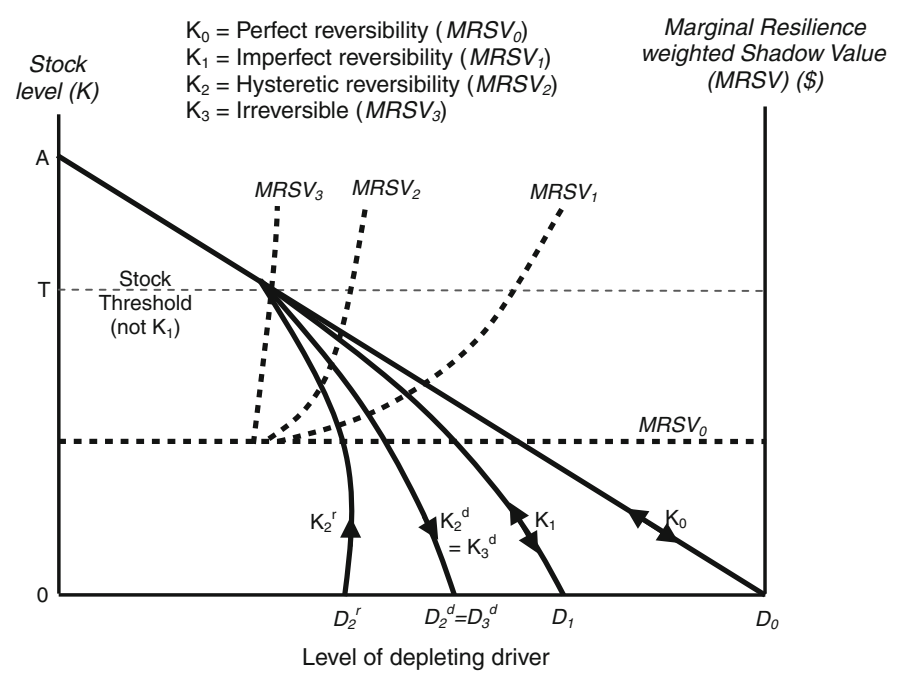

Fig. 6 Trade-off relationships between ecosystem stocks and depletion drivers with corresponding marginal resilience weighted shadow values (MRSV). (For simplicity we assume that these stocks are not substitutes for each other and stock level in all other respects these stocks are identical, yielding equal utility and shadow value where they are not depleted)

To calculate this, a number of assumptions must be made. Most notably, a judgement needs to be arrived at about the ease (or difficulty) with which particular natural assets can be replaced (the 'elasticity of substitution' between this and other assets). The less the potential for such replacement (i.e. lower elasticity of substitution), then the faster the increase in the marginal shadow value of a service as the underlying natural asset becomes scarcer. At the extreme certain natural assets may be 'critical' (Turner and Pearce 1993; Turner et al. 1994; Ekins et al. 2003) in that there are no substitution possibilities available. Such 'critical natural capital' requires particular care as discussed subsequently with respect to safe minimum standards.

\subsection{Resilience Value}

An innovative approach to the problem of assessing sustainability is proposed by Mäler et al. (2009) and Mäler (2008) who considers the ability of an ecosystem to withstand stresses and shocks and so continue to provide services. Mäler et al. propose treating this ecological 'resilience' as a stock with a distinct asset value which can be degraded or enhanced over time.

Walker et al. (2010) provides an empirical application of Mäler's resilience approach examining the value to agriculture in South-East Australia of maintaining a saline free water table (mainly through farmers cutting down trees to expand agriculture). Here agricultural expansion represents a driver depleting the stock of non-salinated soils (measured as the depth of soils for which saline intrusion is not a problem). As this depletion driver is increased so the stock of ecological resilience falls. As the depleting process itself may generate benefits (here agricultural produce) there is a trade-off to be assessed between the benefits of depletion and the fact that losses of resilience may need to be reversed if stocks fall below some threshold level.

The relationship between resilience stocks and depletion drivers can take many forms, the most simple of which is illustrated by function $\mathrm{K}_{0}$ in Fig. 6 . Here the trade off between 
resilience stock and depletion driver is linear and perfectly reversible (i.e. there is no threshold). This implies that a given unit change in the depletion drive (either increase or decrease) results in a constant response (negative or positive) in resilience stocks. The stock of resilience available at any given time will generate a marginal shadow value. We can weight this value by the difficulty of reversing the level of prior depletion and can refer to this as the marginal resilience weighted shadow value (MRSV). ${ }^{69}$ In the case illustrated by function $\mathrm{K}_{0}$, as the relationship between depletion and stocks is perfectly reversible so the MRSV is a constant irrespective of the level of depletion (shown as $\mathrm{MRSV}_{0}$ ).

While function $\mathrm{K}_{0}$ exhibits a constant trade off between depletion drivers and resilience stocks irrespective of the level of the latter, this need not be the case. Other resources may exhibit threshold effects in that once stocks are depleted to some ecologically relevant level then further increases in the depletion driver result in an accelerating rate of stock reductions. This is reflected in the concavity of the stock depletion curve for resource $\mathrm{K}_{1}$. This elevation in the rate of depletion once the threshold is breeched is reflected in the resilience weighted shadow value of $K_{1}$ shown by line $\mathrm{MRSV}_{1}$ which is common with $\mathrm{MRSV}_{0}$ when stocks are above the threshold but then rises above the latter reflecting the elevated rate of depletion.

Despite its threshold effect, stock $\mathrm{K}_{1}$ still exhibits reversibility along the depletion path. However, this need not be the case. Stock $\mathrm{K}_{2}$ also exhibits a threshold effect with depletion path $\mathrm{K}_{2}^{\mathrm{d}}$. However, once complete depletion is arrived at, the reversibility path $\left(\mathrm{K}_{2}^{\mathrm{r}}\right)$ departs from the depletion path. Specifically, the level of the depletion driver has to be significantly reduced before the stock of resilience can begin to recover; ${ }^{70}$ a phenomena known as hysteresis. Such a case is discussed by Walker et al. (2010) who notes that as agriculture in south-east Australia expands it cuts down trees which, due to the hydrological condition of the area, results in an increasing level of ground water salinisation. However, in order to reverse this situation farmers actually need to plant more trees than they originally felled because the elevated salinisation stunts the growth of newly planted trees. The additional costs implicit in having to further reduce depletion drivers (such as agriculture) in order to replenish ecological stocks (here the levels of non-salinised water) implies an elevated post-threshold shadow value of resilience, as illustrated in $\mathrm{MRSV}_{2}$.

Both the imperfect and hysteretic reversibility cases imply that depletion of resources which have ecological thresholds imposes additional welfare losses above those associated with the perfect reversibility case. These elevated shadow values reach a maximum when we consider cases such as resource $\mathrm{K}_{3}$. This follows depletion path $\mathrm{K}_{3}^{\mathrm{d}}$ but once severe depletion is arrived at, reductions in the depletion driver fail to induce recovery in the stock (e.g. extending the Walker et al. case, imagine a situation where induced salinisation meant that all newly planted trees died and restoration was effectively impossible). This results in the extreme shadow value function $\mathrm{MRSV}_{3}$. Note that this and all of the shadow value curves will become even steeper with increasing levels of risk aversion.

The resilience approach to sustainability provides a useful tool for economic analysis of ecosystem assessments. However, as Walker et al., acknowledge, it requires high degrees of knowledge and data availability, particularly when stocks with thresholds are influenced by multiple interacting variables. Therefore, we conclude our review of approaches to sustainability by considering a cruder but simpler method; safe minimum standards.

\footnotetext{
69 Walker et al. 2010 define the MRSV as the probability of a change into an imperfectly reversible state (i.e. the chance of breeching a threshold) multiplied by the damage that such a change will cause.

70 Such resource extraction effects are mirrored by the phenomena of pollution discharges which exceed the ambient environment's capacity to safely assimilate such emissions leading to a long run reduction in that capacity (Pearce 1976; Turner et al. 1994).
} 


\subsection{Safe Minimum Standards}

A safe minimum standard (SMS) can be thought of as a precautionary approach to the management of a natural asset (Ciriacy-Wantrup 1952; Bishop 1978). ${ }^{71}$ Here conventional economic decision making prevails unless a threshold threat is identified at which point the onus of proof shifts away from assuming that development is justified unless the costs to the environment do not justify proceeding, to a presumption that conservation is the right option unless the sacrifice (i.e. the opportunity costs) that it entails is intolerably high. Farmer and Randall (1998) and Randall (2007) argue that the appeal of the SMS lies in it being an approach that may well command broad moral consensus for making decisions. Allied to this is the argument that, in a situation of considerable uncertainty regarding underlying ecological processes, thresholds and economic values (to which we return subsequently), the SMS approach provides a safety-first approach to ensuring the future sustainability of human society through maintenance of the ecosystem stocks and services upon which it is reliant.

This thinking about SMS appears to have influenced conservation policy internationally (Berrens 2001; Pearce 2004), including in the US (e.g. the Endangered Species Act, ESA), Europe (e.g. the EU Birds and Habitats Directives, the Marine Strategy Directive, the Water Framework Directive, the European Landscape Convention, etc.) and the UK (e.g. Public Service Agreement 28, the Environmental Protection Act, Integrated Pollution Prevention and Control, Water Resources and Water Acts, Natural Environment and Rural Communities Act, Wildlife and Countryside Act, Forestry Act and others). Taking a US example, Berrens et al. (1998) investigate the implications of adopting these standards in case studies of two river systems. Common to both cases was the designation of areas of critical habitat for fish species identified as being endangered under the ESA. The sacrifice that this entailed involved restricting human uses of the rivers (by agricultural, industrial and household sectors). One question is where exactly to draw the line as regards when such sacrifice entailed by defending the SMS is too high. This level of 'tolerance' might be determined by the political process, by reference to some notional benchmark (such as an income loss indicators; see Berrens et al. 1998) or if the forgone development causes severe hardship or poverty (Pearce et al. 2006; Randall 2007). However, such considerations need to be balanced against the longterm consequences of ignoring threshold effects. Rockström et al. (2009) discuss numerous assets which exhibit threshold effects ${ }^{72}$ and consider the potential for multiple global triggers of threshold effects, or 'tipping points' (Rockström et al. 2009). They argue that piecemeal abatement strategies are unlikely to be sufficiently effective in the face of such stressors and propose the adoption of a precautionary SMS to maintain the planet within a "safe operating space". For example, in the case of biodiversity loss they advocate a boundary of ten times the background rates of extinction. Because of the many gaps in our knowledge this boundary should be considered as preliminary, but they suggest that the current rate of species loss (100-1,000 times more than what could be considered natural) will lead to significant reductions in ecosystem resilience. ${ }^{73}$

\footnotetext{
71 See also Gren et al. (1994) and Turner et al. (2003) who also argue for a pre-existing 'primary', 'glue' or 'infrastructure' value arising from an intact state for nature.

72 Rockström et al. (2009) identify nine threshold effects: climate change; rate of biodiversity loss; interference with the nitrogen and phosphorus cycles; stratospheric ozone depletion; ocean acidification; global freshwater use; change in land use; chemical pollution and atmospheric aerosol loading. They argue that the first three of these have already reached the threshold zone.

73 In practice the relationship between biodiversity and ecosystem services is complicated and it is not clear that a single threshold has meaning nor that it is best measured in terms of species loss (Díaz et al. 2007). Certain ecosystem services, for example erosion control or carbon sequestration, may be relatively insensitive
} 
The implementation of any global safe minimum standards strategy will be controversial and will require concerted and targeted natural and social science research efforts to underpin it. Globalisation has resulted in a rate and extent of economic activity sufficient to pressurise a range of earth processes simultaneously. Addressing this is likely to require a radical overhaul of the governance processes controlling international trade and finance and resource exploitation etc. (Norgaard 2009). In the interim, recent work by Lenton et al. (2008) has proposed the use of early warning systems using trend analysis and predictive modelling to identify systems that are likely to cross such tipping points.

\section{Concluding Comments}

There is an expanding literature and interest in the concept of ecosystem services as an underpinning guide for decision making. The paper has attempted to contribute to this literature by provide an overview of issues arising from the economic analysis of such ecosystem service assessments. The paper opens by considering a single assessment period during which ecosystem assets are used in a sustainable manner. With these assumptions in place we begin our discussions by developing a terminology for future applications and employ this to focus upon the flow of ecosystems services and their role in generating welfare bearing goods and resultant benefits. We consider the distinction between sustainability analyses of historic trends and assessments of alternative policy options through scenario analyses. Economic analysis of the role and value of ecosystem services begins through isolating their contribution to welfare bearing goods. This contribution is then valued through the application of a range of methods and techniques ranging from adjustments of market prices to the measurement and valuation of preferences for non-market goods.

We illustrate the preceding principles though a case study focusing upon the economic value of the ecosystem services and associated goods arising from land use change. As part of this illustration we consider the central concepts of marginal analysis and substitution effects within economic assessments and relax our single period assumption to discuss the incorporation of multiple period costs and benefits within the assessment of shadow values; a process which introduces the concept of discounting. Finally we relax our assumption that assets are necessarily being managed in a sustainable manner. We consider approaches to incorporating such problems within economic analysis focussing upon the increase in real shadow values which this may induce, the explicit incorporation of resilience values within such analyses and the potential for adopting safe minimum standards as a solution to the depletion of ecosystem assets and the avoidance of stock threshold and tipping point effects.

Footnote 73 continued

to biodiversity and rely more strongly on the extent of structural biomass. On the other hand, ecosystem processes such as productivity and decomposition rates always show a positive relationship with biodiversity measured as functional trait diversity, although the relationship generally saturates at some point. However, empirical and theoretical studies indicate that in the case of long term environmental change or a constantly fluctuating environment, and to realise the full insurance value of biodiversity, much less loss of biodiversity can be tolerated (Yachi and Loreau 1999; Loreau et al. 2001). Finally, in the case of ecosystem service such as the non-use values held for wild species diversity and for potential benefits from bio-prospecting, any loss of diversity in species or genetic terms represents a significant loss and most commentators would not regard rates of loss comparable to those currently witnessed as acceptable. Therefore the role of biodiversity, while needing to be better understood, is probably best evaluated in context as was done for a recent European assessment (EASAC 2009) and as is planned for the UK NEA. 
Given the wealth of issues which have to be embraced within an economic analysis of ecosystem services, our discussion so far has been deliberately uncritical in the main. However, we conclude by briefly touching upon some of the major problems facing such undertakings.

A major issue concerns the substantial gaps in natural science knowledge regarding the processes and interactions through which ecosystem services and provided and maintained. As Farley (2008) notes, the most serious problem facing ecosystem service assessments "is the ignorance and uncertainty concerning ecosystem function" ( $\mathrm{p} 1)$. The past century of natural science research has seen the development of a disciplinary expertise which, although vital in facilitating a deep understanding of individual systems, has inadvertently discouraged the cross-disciplinary cooperation and holism necessary to comprehend the interplay of ecological systems. While recent years have witnessed a marked reversal of this trend with interdisciplinary research being brought to the fore, it is still the case that interactions between systems are relatively poorly understood (Klein 1990, 2004; Lattuca 2001; Rhoten 2004). Furthermore, even this knowledge is stretched to its limits when we consider system interactions within the context of a general and unprecedented stressor such as global climate change. Natural science is being asked to predict into areas beyond the range of prior data and not surprisingly this raises new uncertainties, yet such problems have to be tackled if we are to employ the ecosystem service approach as a useful aid to practical policy and decision making.

Similar concerns and gaps exist within the economic literature. Interdisciplinary research, combining economics and other social sciences with the natural sciences, has advanced significantly over recent decades yet remains a relatively immature area of study conducted by small groups. Not surprisingly then, most natural scientists have little or no experience of the informational requirements for economic analysis (e.g. provision change assessments for economic valuation purposes; damage and threshold analyses for resilience measures, etc.). Furthermore, even within the economics camp, the continuing emphasis upon conventional economic research conducted as a single discipline means that the efforts of environmental and resource economists remain a minority branch of research. For example, even after four decades of research into the valuation of non-market goods such as those provided by the natural environment, the available stock of knowledge remains inadequate given the complexity of the demands upon it. The development of value transfer methods enhances the usefulness of the available literature but cannot make up for an absence of high quality valuation studies regarding key questions such as the impact upon marginal shadow values of depleting ecological stocks and accompanying threshold effects. In the main this situation reflects the very small base from which such research started and its initially slow growth. However, it also indicates an inherent aversion to strategic investment in wider ecosystem service valuation with the focus instead being dictated by short term investment and policy priorities concentrating upon single resources. This results in a degree of uncertainty regarding the value of different provision options which is far from satisfactory and has led some to call for decisions to be made without resort to valuation (e.g. Vatn and Bromley 1994). However, an alternative strategy would be to infer value relationships based upon economic theory and related intuition. For example, while we may have sparse data on the value of a given good, we can nonetheless draw upon theory to infer likely shapes for marginal benefits curves, incorporating diminishing or increasing marginal values as provision levels rise or fall. Furthermore, this issue is overtly acknowledged within the remit of the UK NEA and indeed one of its aims is to identify knowledge gaps for the purposes of directing future research.

Other concerns are well documented yet equally important. An obvious issue is the topic of discounting. Within the conventional paradigm it is still true that, if the bulk of society is as 
some would argue, self obsessed and relatively uninterested in others, including future generations, then a discounting regime which reflects that will lead to economic analyses which maximise present generation benefits even if outcomes are ecologically unsustainable. We have reviewed potential solutions such as precautionary safe minimum standards or ethics based discounting, yet to date these are not the generally accepted norm.

A further well established concern is that economic valuations generally reflect the current distribution of income with those with higher ability to pay being better able to reflect their preferences through higher willingness to pay. Arguably this is not a concern given that most decisions are predicated on existing income distributions and consequent demand. However, from an economic welfare perspective such situations may very well not optimise social wellbeing. In a manner similar to the discounting issue, solutions are available. For example, within the Treasury (2003) official UK decision making guidelines higher weighting is accorded to lower income groups because of the greater value of income gains to the latter. ${ }^{74}$ It should be noted however that, despite the official acceptability of such approaches, they are rarely implemented within economic analyses of ecosystem services. The UK NEA seeks to remedy this situation by undertaking such adjustments where data permits.

In conclusion then, we have attempted throughout the main body of this paper to provide an overview of the variety of issues raised by the application of economic analysis techniques to ecosystem service assessments. As noted, these are complex analyses and as we acknowledge above, the issues raised are not settled and the available literature less than complete. Nevertheless the importance of incorporating ecosystems services within policy appraisal and decision making techniques cannot be understated; it is literally a life and death issue for the future of human society and the difficulties raised cannot be shirked or the task ignored. Many would argue that there is no more important issue facing the natural and social sciences today.

Open Access This article is distributed under the terms of the Creative Commons Attribution Noncommercial License which permits any noncommercial use, distribution, and reproduction in any medium, provided the original author(s) and source are credited.

\section{References}

Adamowicz W, Louviere J, Williams M (1994) Combining revealed and stated preference methods for valuing environmental amenities. J Environ Econ Manage 26(3):271-292

Adger WN, Brown K, Shiel RS, Whitby MC (1992) Carbon dynamics of land use in Great Britain. J Environ Manage 36:117-133

Arnade C, Kelch D (2007) Estimation of area elasticities from a standard profit function. Am J Agric Econ 89:727-737

Arrow KJ, Dasgupta P, Goulder LH, Mumford K, Oleson K (2007) China, the US, and sustainability: perspectives based on comprehensive wealth. Stanford working paper

Ayres RU (2007) On the practical limits to substitution. Ecol Econ 61(1):115-128. doi:10.1016/j.ecolecon. 2006.02.011

Badola R, Hussain SA (2005) Valuing ecosystem functions: an empirical study on the storm protection function of Bhitarkanika mangrove ecosystem, India. Environ Conserv 32(1):85-92

Balmford A, Bruner A, Cooper P, Constanza R, Farber S, Green RE, Jenkins M, Jefferis P, Jessamy V, Madden J, Munro K, Myers N, Naeem S, Paavola J, Rayment M, Rosendo S, Roughgarden J, Trumper K, Turner RK (2002) Economic reasons for conserving wild nature. Science 297:950-953. doi:10.1126/science. 1073947

74 See also the income reweighting approach to implementing cost-benefit analysis discussed by Pearce (1983). 
Banzhaf HS, Burtraw D, Evans D, Krupnick A (2006) Valuation of natural resource improvements in the adirondacks. Land Econ 82(3):445-464

Barbier EB (1994) Valuing environmental functions: tropical wetlands. Land Econ 70:155-173

Barbier EB (2000) Valuing the environment as input: applications to mangrove-fishery linkages. Ecol Econ $35: 47-61$

Barbier EB (2003) Habitat-fishery linkages and mangrove loss in Thailand. Contemp Econ Policy 21(1):59-77

Barbier EB (2007) Valuing ecosystem services as productive inputs. Econ Policy 22:177-229

Barbier EB (2009) Ecosystems as natural assets. Found Trends Microecon 4(8):611-681

Barbier EB, Koch EW, Silliman BR, Hacker SD, Wolanski E, Primavera J, Granek EF, Polasky S, Aswani S, Cramer LA, Stoms DM, Kennedy CJ, Bael D, Kappel CV, Perillo GM, Reed DJ (2008) Coastal ecosystem-based management with nonlinear ecological functions and values. Science 319:321-323

Barbier EB, Markandya A, Pearce DW (1990) Environmental sustainability and cost—benefit analysis. Environ Plann A 22(9):1259-1266

Bartelmus P (2001) Accounting for sustainability: greening the national accounts. In: Tolba MK (ed) Our fragile world, forerunner to the encyclopedia of life support systems II. Eolss Publishers, Oxford, pp $1721-1735$

Bartelmus P (2008) Quantitative eco-nomics, how sustainable are our economies? Springer Science and Business Media, Secaucus NJ and Heidelberg

Barton DN (2002) The transferability of benefit transfer: contingent valuation of water quality improvements in Costa Rica. Ecol Econ 42:147-164

Bateman IJ (2007) Valuing preferences regarding environmental change. In: Pretty J, Ball A, Benton T, Guivant J, Lee D, Orr D, Pfeffer M, Ward H (eds) The SAGE handbook of environment and society. Sage, London, pp 155-171

Bateman IJ (2009a) Economic analysis for ecosystem assessments: application to the UK national ecosystem assessment (NEA). CSERGE working paper EDM 09-12, Centre for Social and Economic Research on the Global Environment, University of East Anglia

Bateman IJ (2009b) Bringing the real world into economic analyses of land use value: incorporating spatial complexity. Land Use Policy 26:S30-S42. doi:10.1016/j.landusepol.2009.09.010

Bateman IJ, Jones AP (2003) Contrasting conventional with multi-level modelling approaches to meta-analysis: an illustration using UK woodland recreation values. Land Econ 79(2):235-258

Bateman IJ, Carson RT, Day B, Hanemann WM, Hanley N, Hett T, Jones-Lee M, Loomes G, Mourato S, Özdemiroğlu E, Pearce DW, Sugden R, Swanson J (2002a) Economic valuation with stated preference techniques: a manual. Edward Elgar Publishing, Cheltenham

Bateman IJ, Jones AP, Lovett AA, Lake I, Day BH (2002b) Applying geographical information systems (GIS) to environmental and resource economics. Environ Resour Econ 22(1-2):219-269. doi:10.1023/ A: 1015575214292

Bateman IJ, Lovett AA, Brainard JS (2003) Applied environmental economics: a GIS approach to cost-benefit analysis. Cambridge University Press, Cambridge

Bateman IJ, Day BH, Georgiou S, Lake I (2006) The aggregation of environmental benefit values: welfare measures, distance decay and total WTP. Ecol Econ 60(2):450-460. doi:10.1016/j.ecolecon.2006.04. 003

Bateman IJ, Burgess D, Hutchinson WG, Matthews DI (2008a) Contrasting NOAA guidelines with learning design contingent valuation (LDCV): preference learning versus coherent arbitrariness. J Environ Econ Manage 55:127-141. http://dx.doi.org/10.1016/j.jeem.2007.08.003

Bateman IJ, Munro A, Poe GL (2008b) Asymmetric dominance effects in choice experiments and contingent valuation. Land Econ 84:115-127. http://le.uwpress.org/cgi/reprint/84/1/115

Bateman IJ, Day BH, Dupont D, Georgiou S (2009a) Procedural invariance testing of the one-and-one-halfbound dichotomous choice elicitation method. Rev Econ Stat 91(4):806-820. doi:10.1162/rest.91.4. 806

Bateman IJ, Day BH, Jones AP, Jude S (2009b) Reducing gains/loss asymmetry: a virtual reality choice experiment (VRCE) valuing land use change. J Environ Econ Manag 58:106-118. doi:10.1016/j.jeem.2008. 05.003

Bateman IJ, Coombes E, Fisher B, Fitzherbert E, Glew DW, Naidoo R (2009c) Saving sumatra's species: combining economics and ecology to define an efficient and self-sustaining program for inducing conservation within oil palm plantations. In: CSERGE working paper EDM-2009-03, centre for social and economic research on the global environment. University of East Anglia

Bateman IJ, Brouwer R, Ferrini S, Schaafsma M, Barton DN, Dubgaard A, Hasler B, Hime S, Liekens I, Navrud S, De Nocker L, Ščeponavičiūtė R, Semėnienė D (2009d) Making benefit transfers work: deriving and testing principles for value transfers for similar and dissimilar sites using a case study of the 
non-market benefits of water quality improvements across Europe. In: CSERGE working paper EDM 09-10, centre for social and economic research on the global environment. University of East Anglia

Bateman IJ, Fisher B, Fitzherbert E, Glew D, Naidoo R (2010a) Tigers, markets and palm oil: market potential for conservation. Oryx 44(2):230-234. doi:10.1017/S0030605309990901

Bateman IJ, Brouwer R, Cranford M, Hime S, Ozdemiroglu E, Phang Z, Provins A (2010b) Valuing environmental impacts: practical guidelines for the use of value transfer in policy and project appraisal, main report to the department for environment, food and rural Affairs. Economics for the Environment Consultancy (eftec), London. Published at http://www.defra.gov.uk/environment/policy/ natural-environ/documents/guidelines.pdf

Bateman IJ, Binner A, Coombes E, Day BH, Ferrini S, Fezzi C, Hutchins M, Posen P (2010c) Integrated and spatially explicit modelling of the economic value of complex environmental change and its knock-on effects. In: Presented at the 4th world congress of environmental and resource economists (WCERE2010), Montreal, Canada, 28 June-2 July 2010

Beckerman W, Hepburn C (2007) Ethics of the discount rate in the stern review on the economics of climate change. World Econ 8:187-210

Bergland O, Magnussen K, Navrud S (1995) Benefit transfer: testing for accuracy and reliability. In: Florax RJGM, Nijkamp P, Willis KG (eds) (2002) comparative environmental economic assessment. Edward Elgar, UK

Berrens RP (2001) The safe minimum standard of conservation and endangered species: a review. Environ Conserv 28:104-116

Berrens RP, Brookshire DS, McKee M, Schmidt C (1998) Implementing the safe minimum standard approach: two case studies from the US endangered species act. Land Econ 74(2):147-161

Bishop R (1978) Endangered species and uncertainty: the economics of a safe minimum standard. Am J Agric Econ 60:10-18

Bockstael NE, McConnell KE (2006) Environmental and resource valuation with revealed preferences: a theoretical guide to empirical models, the economics of non-market goods and services, vol 7. Springer, Dordrecht

Bockstael NE, Freeman AM III, Kopp RJ, Portney PR, Smith VK (2000) On measuring economic values for nature. Environ Sci Technol 34:1384-1389

Boscolo M, Vincent JR (2003) Nonconvexities in the production of timber, biodiversity, and carbon sequestration. J Envir Econ Manage 46:251-268

Boyd J, Banzhaf S (2007) What are ecosystem services? The need for standardized environmental accounting units. Ecol Econ 63:616-626

Boyd JW, Krupnick A (2009) The definition and choice of environmental commodities for nonmarket valuation. RFF Discussion Paper 09-35. Resources for the Future, Washington

Brander LM, Florax RJGM, Vermaat JE (2006) The empirics of wetland valuation: a comprehensive summary and a meta-analysis of the literature. Envir Resour Econ 33:223-250. doi:10.1007/s10640-005-3104-4

Brouwer R (2000) Environmental value transfer: state of the art and future prospects. Ecol Econ 32:137-152

Brouwer R, Bateman IJ (2005) Benefits transfer of willingness to pay estimates and functions for health-risk reductions: a cross-country study. J Health Econ 24: 591-611. doi:10.1016/j.jealeco.2004.09.004

Brouwer R, Langford IH, Bateman IJ, Turner RK (1999) A meta-analysis of wetland contingent valuation studies. Reg Envir Chang 1(1):47-57

Brouwer R, Spanninks FA (1999) The validity of environmental benefits transfer: further empirical testing. Environ Resour Econ 14(1):95-117

Cairns RD (2002) Green accounting using imperfect, current prices. Environ Dev Econ 7(2):207-214

Carlsson F, Frykblom P, Lijenstolpe C (2003) Valuing wetland attributes: an application of choice experiments. Ecol Econ 47:95-103

Carpenter SR, Mooney HA, Agard J, Capistrano D, DeFries RS, Diaz S, Dietz T, Duraiappah AK, Oteng-Yeboah A, Pereira HM, Perrings C, Reid WV, Sarukhan J, Scholes RJ, Whyte A (2009) Science for managing ecosystem services: beyond the millennium ecosystem assessment. Proc Natl Acad Sci USA 106:1305-1312

Carson RT, Flores NE, Martin KM, Wright JL (1996) Contingent valuation and revealed preference methodologies: comparing the estimates for quasi-public goods. Land Econ 72:80-99

Carson RC, Mitchell R, Hanemann WM, Kopp R, Presser S, Ruud P (2003) Contingent valuation and lost passive use: damages from the exxon valdez oil spill. Environ Resour Econ 25(3):257-286

Champ PA, Boyle K, Brown TC (eds) (2003) A primer on non-market valuation, the economics of non-market goods and services, vol 3. Kluwer Academic Press, Dordrecht

Chapin FS III, Zavaleta ES, Valerie TE, Naylor RL, Vitousek PM, Reynolds HL, Hooper DU, Lavorel S, Sala OE, Hobbie SE, Mack MC, Díaz S (2000) Consequences of changing biodiversity. Nature 405:234-242. doi:10.1038/35012241 
Chiang AC (1984) Fundamental methods of mathematical economics. McGraw Hill, New York

Chichilnisky G, Heal GM (1998) Economic returns from the biosphere. Nature 391:629-630

Christie M, Hanley N, Warren J, Murphy K, Wright R, Hyde T (2006) Valuing the diversity of biodiversity. Ecol Econ 58:304-317

Ciriacy-Wantrup Sv (1952) Resource conservation: economics and policies. University of California Press, Berkeley

Considine TJ, Larson DF (2006) The environment as a factor of production. J Environ Econ Manage 52: 645-662

Conventionon on Biological Diversity (CBD) (2006) Global biodiversity outlook 2. Secretariat of the Convention on Biological Diversity, Montreal

Costanza R, d'Arge R, Groot Rd, Farber S, Grasso M, Hannon B, Limburg K, Naeem S, O’Neill RV, Paruelo J, Raskin RG, Sutton P, Belt Mvd (1997) The value of the world's ecosystem services and natural capital. Nature 387:253-260

Costanza R, Pérez-Maqueo O, Martinez ML, Sutton P, Anderson SJ, Mulder K (2008) The value of coastal wetlands for hurricane protection. Ambio 37:241-248

Daily G (1997) Nature's services: societal dependence on natural ecosystems. Island Press, Washington

Dasgupta P (2001) Human wellbeing and the natural environment. Oxford University Press, Oxford

Dasgupta P (2007) Comments on the stern review's economics of climate change. Natl Inst Econ Rev 199:4-7

Dasgupta P (2009) The welfare economic theory of green national accounts. Environ Resour Econ 42(1):3-38. doi:10.1007/s10640-008-9223-y

Dasgupta P, Mäler K-G (2000) Net national product, wealth, and social well-being. Environ Dev Econ 5(1):69-93

Day BH, Bateman IJ, Lake I (2007) Beyond implicit prices: recovering theoretically consistent and transferable values for noise avoidance from a hedonic property price model. Environ Resour Econ 37(1):211-232. doi:10.1007/s10640-007-9121-8

De Groot RS, Wilson MA, Boumans RMJ (2002) A typology for the classification, description and valuation of ecosystem functions, goods and services, special issue on the dynamics and value of ecosystem services: integrating economic and ecological perspectives. Ecol Econ 41:393-408

Defra (2009) Farm accounts in England: results of the farm business survey. Department for Environment Food \& Rural Affairs, London

Desvousges WH, Naughton MC, Parsons GR (1992) Benefit transfer: conceptual problems in estimating water quality benefits using existing studies. Water Resour Res 28(3):675-683

Díaz S, Lavorel S, de Bello F, Quétier F, Grigulis K, Robson M (2007) Incorporating plant functional diversity effects in ecosystem service assessments. Proc Natl Acad Sci USA 104:20684-20689

Dietz S, Hepburn C (2010) On non-marginal cost-benefit analysis. Grantham Research Institute on Climate Change and the Environment, London School of Economics and Political Science, London

Dietz S, Anderson D, Stern N, Taylor C, Zenghelis D (2007) Right for the right reasons: a final rejoinder on the stern review. World Econ 8:229-258

Downing M, Ozuna T (1996) Testing the reliability of the benefit function transfer approach. J Environ Econ Manage 30:316-322

EASAC (2009) Ecosystem services and biodiversity in Europe. EASAC policy report 09 European Academies Science Advisory Council, London

Eaton MA, Brown AF, Noble DG, Musgrove AJ, Hearn R, Aebischer NJ, Gibbons DW, Evans A, Gregory RD (2009) Birds of conservation concern 3: the population status of birds in the United Kingdom, Channel Islands and the Isle of man. Br Birds 102:296-341

Egan K, Herriges JA (2006) Multivariate count data regression models with individual panel data from an on-site sample. J Environ Econ Manage 52(2):567-581

Ekins P, Folke C, De Groot R (2003) Identifying critical natural capital. Ecol Econ 44(2-3):159-163

Ellis GM, Fisher AC (1987) Valuing the environment as input. J Environ Manage 25:149-156

Environment Agency (2001) Water resources for the future: a strategy for England and Wales. UK Environment Agency, London

Farley J (2008) Valuing natural capital: the limits of marginal valuation in complex systems. In: Presented at economics and conservation in the tropics: a strategic dialogue, the conservation strategy fund, resources for the future, and the gordon and betty moore foundation, San Francisco, January 31-February 12008

Farmer MC, Randall A (1998) The rationality of a safe minimum standard. Land Econ 74:287-302

FBU (Farm Business Unit) (2009) Farm business survey in wales. University of Wales, Aberystwyth

Federal Register (1995) Federal guidance for the establishment, use and operation of mitigation banks. Fed Regist 60(228):58605-58614

Fezzi C, Bateman IJ (2009) Structural agricultural land use modelling. In: Presented at The XXVII international conference of agricultural economists, Beijing, China, 16th-22nd August 2009. Available at http:// ageconsearch.umn.edu/handle/51423 
Fezzi C, Bateman IJ (2010) The impact of climate change on agriculture: a panel ricardian analysis using GAMMs. In: Presented at envecon 2010: applied environmental economics conference, 12th March 2010. The Royal Society, London

Finnoff D, Tschirhart J (2008) Linking dynamic economic and ecological general equilibrium models. Resour Energy Econ 30:91-114

Fisher B, Turner RK (2008) Ecosystem services: classification for valuation. Biol Conserv 141(5):1167-1169

Fisher B, Turner RK, Zylstra M, Brouwer R, De Groot R, Farber S, Ferraro P, Green R, Hadley D, Harlow J, Jefferiss P, Kirkby C, Morling P, Mowatt S, Naidoo R, Paavola J, Strassburg B, Yu D, Balmford A (2008) Ecosystem services and economic theory: integration for policy-relevant research. Ecol Appl 18(8):2050-2067

Foresight Land Use Futures Project (2010) Final project report. The Government Office for Science, London Freeman AM III (1991) Valuing environmental resources under alternative management regimes. Ecol Econ 3:247-256

Freeman AMIII (2003) The measurement of environmental and resource values: theory and methods, 2 nd edn. Resources for the Future, Washington

Gerlagh R, van der Zwaan BCC (2002) Long-term substitutability between environmental and man-made goods. J Environ Econ Manage 44:329-345

Global Environment Facility (GEF) (1998) Valuing the global environment: actions and investments for a 21st century. GEF, Washington

Godoy R, Lubowski R, Markandya A (1993) A method for the economic valuation of non-timber forest products. Econ Bot 47:220-233

Gren I-M, Elofsson K, Jannke P (1997) Cost-effective nutrient reductions to the Baltic Sea. Environ Resour Econ 10:341-362

Gren I-M, Folke C, Turner RK, Bateman IJ (1994) Primary and secondary values of wetland ecosystems. Environ Resour Econ 4:55-74

Griffin RC, Montgomery JM, Rister ME (1987) Selecting functional form in production function analysis. West J Agric Econ 12(02):216-227

Groom B, Hepburn C, Koundouri P, Pearce DW (2005) Declining discount rates: the long and the short of it. Environ Resour Econ 33:445-493

Guyomard H, Baudry M, Carpentier A (1996) Estimating crop supply response in the presence of farm programmes: application to the CAP. Eur Rev Agric Econ 23:401-420

Haab TC, McConnell KE (2002) Valuing environmental and natural resources. Edward Elgar Publishing, Cheltenham

Haines-Young R, Potschin M, de Groot D, Kienast F, Bolliger J (2009) Towards a common international classification of ecosystem services (CICES) for integrated environmental and economic accounting (Draft V1). In: Report to the European environment agency for contract No: No. EEA/BSS/07/007, centre for environmental management. School of Geography, University of Nottingham

Hamilton K, Clemens M (1999) Genuine Saving in developing countries. World Bank Econ Rev 13(2):333356

Hamilton K, Withagen C (2007) Savings growth and the path of utility. Can J Econ 40(2):703-713

Hamilton K, Ruta G (2009) Wealth accounting, exhaustible resources and social welfare, themed issue: advances in the theory and practice of environmental accounting. Environ Resour Econ 42(1):53-64

Hanley N, Barbier EB (2009) Pricing nature: cost-benefit analysis and environmental policy-making. Edward Elgar, London

Hanley N, MacMillan D, Patterson I, Wright R (2003) Economics and the design of nature conservation policy: a case study of wild goose conservation in scotland using choice experiments. Anim Conser 6:123-129

Hansen L, Hellerstein D (2007) The value of the reservoir services gained with soil conservation. Land Econ 83(3):285-301

Hargrove C (1992) Weak anthropocentric intrinsic value. Monist 75:183-207

Heal G (2000) Valuing ecosystem services. Ecosystems 3(1):24-30

Heal GM, Barbier EB, Boyle KJ, Covich AP, Gloss SP, Hershner CH, Hoehn JP, Pringle CM, Polasky S, Segerson K, Shrader-Frechette K (2005) Valuing ecosystem services: toward better environmental decision making. The National Academies Press, Washington

Hearne RR, Salinas J (2002) The use of choice experiments in the analysis of tourist preferences for ecotourism development in costa rica. J Environ Manage 65:153-163

Herriges JA, Kling CL, Phaneuf DJ (2004) What's the use? Welfare estimates from revealed preference models when weak complementarity does not hold. J Environ Econ Manage 47(1):53-68

Hoel M, Sterner T (2007) Discounting and relative prices. Clim Change 84:265-280

House of Commons Environmental Audit Committee (2007) Government response to the committee's first report of session 2006-07: the UN millennium ecosystem assessment. HC 848, The Stationery Office Limited, London 
Howarth RB, Farber S (2002) Accounting for the value of ecosystem services. Ecol Econ 41:421-429

Hulme M, Jenkins GL, Lu X, Turnpenny JR, Mitchell TD, Jones RG, Lowe J, Murphy JM, Hassell D, Boorman P, McDonald R, Hill S (2002) Climate change scenarios for the United Kingdom: the UKCIP02 scientific report. Tyndall Centre for Climate Change Research, School of Environmental Sciences, University of East Anglia, Norwich, UK, p 120

Huybers T, Bennett J (2003) Environmental management and the competitivenes of nature-based tourism. Environ Resour Econ 24:213-233

IPCC (1996) Climate change 1995: economic and social dimensions of climate change. Cambridge University Press, Cambridge

IPCC (2000) Special report on emissions scenarios (SRES). In: Nakicenovic N, Swart R (eds) International panel on climate change. Cambridge University Press, Cambridge, p 612

Johnstone RJ, Duke JM (2009) Willingness to pay for land preservation across states and jurisdictional scale: implications for benefit transfer. Land Econ 85(2):217-237

Johnston RJ, Besedin EY, Iovanna R, Miller CJ, Wardwell RF, Ranson MH (2005) Systematic variation in willingness to pay for aquatic resource improvements and implications for benefit transfer: a metaanalysis. Can J Agric Econ 53:221-248

Johnston RJ, Ranson MH, Besedin EY, Helm EC (2006) What determines willingness to pay per fish? A meta-analysis of recreational fishing values. Mar Resour Econ 21:1-32

Kahneman D, Wakker P, Sarin R (1997) Back to Bentham? Exploration of experienced utility. Q J Econ 112:373-405

Kaiser B, Roumasset J (2002) Valuing indirect ecosystem services: the case of tropical watersheds. Environ Dev Econ 7:701-714

Kanninen B (ed) (2006) Valuing environmental amenities using stated choice studies: a common sense approach to theory and practice, the economics of non-market goods and services, vol 8. Springer, Dordrecht

Kaval P (2010) A summary of ecosystem service economic valuation methods and recommendations for future studies. Working paper series \#10Department of Economics, University of Waikato

Kim S-H, Dixon JA (1986) Economic valuation of environmental quality aspects of upland agricultural projects in Korea. In: Dixon JA, Hufschmidt MM (eds) Economic valuation techniques for the environment: a case study workbook. Johns Hopkins Press, Baltiimore

Klein JT (1990) Interdisciplinarity: history, theory, and practice. Wayne State University Press, Detroit

Klein JT (2004) Prospectus for transdisciplinarity. Futures 36:515-526

Knowler D, Barbier EB (2005) Managing the Black Sea anchovy fishery with nutrient enrichment and a biological invader. Mar Resour Econ 20:263-285

Knowler D, Barbier EB, Strand I (2001) An open-access model of fisheries and nutrient enrichment in the Black Sea. Mar Resour Econ 16:195-217

Koziell I (2001) Diversity not adversity: sustaining livelihoods with biodiversity. International Institute for Environment and Development and Department for International Development (DFID). England

Krutilla J, Fisher AC (1974) The economics of natural environments. Johns Hopkins University Press, Baltimore

Lattuca L (2001) Creativity interdisciplinarity: interdisciplinary research and teaching among college and university faculty. Vanderbilt University Press, Nashville

Layard R (2005) Happiness: lessons from a new science. Penguin Books, London

Lenton TM, Held H, Kriegler E, Hall JW, Lucht W, Rahmstorf S, Schellnhuber HJ (2008) Tipping elements in the Earth's climate system. PNAS 105:1786-1793

Leon-Gonzalez R, Scarpa R (2008) Improving multi-site benefit functions via Bayesian model averaging: a new approach to benefit transfer. J Environ Econ Manage 56(1):50-68

Lindhjem HL, Navrud HL (2008) How reliable are meta-analyses for international benefit transfers? Ecol Econ 66:425-435

Liu S, Costanza R, Farber S, Troy A (2010) Valuing ecosystem services. Ann N Y Acad Sci 1185:54-78. doi:10.1111/j.1749-6632.2009.05167.x

Loreau M, Naeem S, Inchausti P, Bengtsson J, Grime JP, Hector A, Hooper DU, Huston MA, Raffaelli D, Schmid B, Tilman D, Wardle DA (2001) Biodiversity and ecosystem functioning: current knowledge and future challenges. Science 294:804-808

Loreau M, Oteng-Yeboah A, Arroyo MTK, Babin D, Barbault R, Donoghue M, Gadgil M, Häuser C, Heip C, Larigauderie A, Ma K, Mace G, Mooney HA, Perrings C, Raven P, Sarukhan J, Schei P, Scholes RJ, Watson RT (2006) Diversity without representation. Nature 442:245-246. doi:10.1038/442245a

Mäler K-G (1974) Environmental economics: a theoretical inquiry. Resources for the Future, Baltimore

Mäler K-G (2008) Sustainable development and resilience in ecosystems. Environ Resour Econ 39(1):17-24 
Mäler K-G, Aniyar S, Jansson $\AA$ (2008) Accounting for ecosystem services as a way to understand the requirements for sustainable development. PNAS 105(28):9501-9506. www.pnas.org/cgi/doi/10.1073/ pnas.0708856105

Mäler K-G, Aniyar S, Jansson Å (2009) Accounting for ecosystems. Environ Resour Econ 42:39-51

Mansfield C, Phaneuf DJ, Johnson FR, Yang J-C, Beach R (2008) Preferences for public lands management under competing uses: the case of yellowstone national park. Land Econ 84(2):282-305

Mardle S, James C, Pipitone C, Kienzle M (2004) Bioeconomic interactions in an established fishing exclusion zone: the gulf of castellammare, NW Sicily. Nat Resour Model 17(4):393-447

Mendelsohn R, Nordhaus W, Shaw D (1994) The impact of global warming on agriculture: a ricardian analysis. Am Econ Rev 84:753-771

Millennium Ecosystem Assessment (MA) (2003) Ecosystems and human well-being: a framework for assessment. Island Press, Washington

Millennium Ecosystem Assessment (MA) (2004) Scenarios working group (unpublished report). www. millenniumassessment.org

Millennium Ecosystem Assessment (MA) (2005) Ecosystems and human well-being: a framework for assessment. Island Press, Washington DC

Moeltner K, Boyle KJ, Paterson RW (2007) Meta-analysis and benefit transfer for resource valuation-addressing classical challenges with Bayesian modeling. J Environ Econ Manage 53(2):250-269

Moore MR, Gollehon NR, Carey MB (1994) Multicrop production decisions in western irrigated agriculture: the role of water price. Am J Agric Econ 76:859-874

Murphy J, Sexton D, Jenkins G, Boorman P, Booth B, Brown K, Clark R, Collins M, Harris G, Kendon L (2009) Climate change projections. UK Climate Impacts Programme, Met Office Hadley Centre

Muthke T, Holm-Mueller K (2004) National and international benefit transfer testing with a rigorous test procedure. Environ Resour Econ 29:323-336

Naidoo R, Adamowicz WL (2005) Biodiversity and nature-based tourism at forest reserves in Uganda. Environ Dev Econ 10:159-178

Nalle DJ, Montgomery CA, Arthur JL, Polasky S, Schumaker NH (2004) Modeling joint production of wildlife and timber. J Environ Econ Manage 48(3):997-1017

Navrud S, Ready R (eds) (2007) Environmental value transfer: issues and methods. Springer, Dordrecht

Naylor R, Drew M (1998) Valuing mangrove resources in Kosrae, Micronesia. Environ Dev Econ 3:471-490

Nicholson E, Mace GM, Armsworth PR, Atkinson G, Buckle S, Clements T, Ewers RM, Fa JE, Gardner TA, Gibbons J, Grenyer R, Metcalfe R, Mourato S, Muûls M, Osborn D, Reuman DC, Watson C, Milner-Gulland EJ (2009) Priority research areas for ecosystem services in a changing world. J Appl Ecol 46:1139-1144

Norgaard R (2009) Ecosystem services: from eye-opening metaphor to complexity blinder. Ecol Econ 69(6):1219-1227. doi:10.1016/j.ecolecon.2009.11.009

Nordhaus WD (2007) A review of the stern review on the economics of climate change. J Econ Lit 45:686-702

Office of Science \& Technology (OST) (1999) The use of scenarios in Foresight. An information document prepared for the OST by Professor David Stout. www.foresight.gov.uk

Office of Science \& Technology (OST) (2003) Foresight futures 2020: revised scenarios and guidance. Department for Trade \& Industry, UK, p 38. www.foresight.gov.uk

Oswald AJ, Wu S (2010) Objective confirmation of subjective measures of human well-Being: evidence from the USA. IZA Discussion paper no. 4695, Institute for the Study of Labor (IZA), Bonn

Othman J, Bennett J, Blamey R (2004) Environmental management and resource management options: a choice modelling experience in malaysia. Environ Dev Econ 9:803-824

Oude LA, Peerlings J (1996) Modelling the new EU cereals and oilseeds regime in the Netherlands. Eur Rev Agric Econ 23:161-178

Pachauri RK, Reisinger A (eds) (2007) Contribution of working groups I, II and III to the fourth assessment report of the intergovernmental panel on climate change. IPCC, Geneva

Pagiola S, Ritter Kv, Bishop JT (2004) How much is an ecosystem worth? Assessing the economic value of conservation. The World Bank, Washington

Pascal U, Muradian R, Gómez-Baggethun E, Armsworth P, Brander L, Cornelissen H, Farley J, Loomes J, Martinez-López B, Pearson L, Perrings C, Polasky S, Verma M (2009) Valuation of ecosystems services: methodology and challenges. In: Report to review of the economics of ecosystems and biodiversity. European Commission/ UNEP/ BMU-Germany

Pearce DW (1976) The limits of CBA as a guide to environmental policy. Kyklos 29(1):97-112. doi:10.1111/ j.1467-6435.1976.tb01962.x

Pearce DW (1983) Cost benefit analysis, 2nd edn. Macmillan, NY

Pearce DW (2004) Does european union Environmental policy pass a cost-benefit test? World Econ 5:115-138

Pearce DW, Atkinson G, Mourato S (2006) Cost-benefit analysis and the environment: recent developments. Organisation for Co-operation and Development (OECD), Paris 
Pearce DW, Markandya A, Barbier EB (1989) Blueprint for a green economy. Earthcan, London

Perman R, Ma Y, McGilvray J (1996) Natural resource and environmental economics. Addison Wesley, New York

Pinnegar JK, Viner D, Hadley D, Dye S, Harris M, Berkout F, Simpson M (2006) Alternative future scenarios for marine ecosystems: technical report. Cefas Lowestoft, p 109

Prime Minister's Strategy Unit (PMSU) (2004) Net benefits: a sustainable and profitable future for UK fishing. Prime Minister's Strategy Unit, Cabinet Office, UK. p 168. http://www.number-10.gov.uk/su/fish/index. htm

Randall A (1994) A difficulty with the travel cost method. Land Econ 70:88-96

Randall A (2007) Benefit cost analysis and a safe minimum standard. In: Atkinson G, Dietz S, Neumayer E (eds) Handbook of sustainable development. Edward Elgar, Cheltenham

Ready R, Navrud R, Day B, Dubourg R, Machado F, Mourato S, Spaninks F, Vázquez Rodriquez MX (2004) Benefit transfer in Europe: how reliable are transfers between countries? Environ Resour Econ 29:67-82

Rhoten D (2004) Interdisciplinary research: trend or transition. Items Issues 5(1-2):6-11

Ricketts TH, Gretchen GC, Ehrlich PR, Michener CD (2004) Economic value of tropical forests to coffee production. Proc Nat Acad Sci 101(34):12579-12582

Rockström J, Steffen W, Noone K, Persson A, Chapin FSIII, Lambin EF, Lenton TM, Scheffer M, Folke C, Schellnhuber HJ, Nykvist B, de Wit CA, Hughes T, van der Leeuw S, Rodhe H, Sorlin S, Snyder PK, Costanza R, Svedin U, Falkenmark M, Karlberg L, Corell RW, Fabry VJ, Hansen J, Walker B, Liverman D, Richardson K, Crutzen P, Foley JA (2009) A safe operating space for humanity. Nature 461(7263):472-475

Rodriguez JP, Beard TD, Bennett EM, Cumming GS, Cork SJ, Agard J, Dobson AP, Peterson GD (2006) Trade-offs across space, time, and ecosystem services. Ecol Soc 11(1):28

Rodwell LD, Barbier EB, Roberts CM, McClanahan TR (2002) A model of tropical marine reserve-fishery linkages. Nat Resour Model 15(4):453-486

Rolfe J, Bennett J, Louviere J (2000) Choice modelling and its potential application to tropical rainforest preservation. Ecol Econ 35:289-302

Rosado M, Cunha-e-Sa MA, Ducla-Soares MM, Rainho Catela Nunes LM (2000) Combining averting behavior and contingent valuation data: an application to drinking water treatment (2000) FEUNL working paper no. 392. Available at SSRN: http://ssrn.com/abstract=880458

Rosenberger RS, Peterson GL, Clarke A, Brown TC (2003) Measuring dispositions for lexicographic preferences of environmental goods: integrating economics, psychology and ethics. Ecol Econ 44(1):63-76

Schenkler W, Hanemann WM, Fisher A (2005) Will US agriculture really benefit from global warming? Accounting for irrigation in the hedonic approach. Am Econ Rev 95:395-406

Seo N, Mendelsohn R, Dinar A, Hassan R, Kurukulasuriya P (2009) A ricardian analysis of the distribution of climate change impacts on agriculture across agro-ecological zones in Africa. Environ Resour Econ 43(3):313-332

Smith MD (2007) Generating value in habitat-dependent fisheries: the importance of fishery management institutions. Land Econ 83:59-73

Spash CC (2008) Deliberative monetary valuation and the evidence for a new value theory. Land Econ 84:469488

Stern NH (2007) The economics of climate change: the Stern review. Cambridge University Press, Cambridge

Sterner T, Persson UM (2008) An even sterner review: introducing relative prices into the discounting debate. Rev Environ Econ Policy 2(1):61-76

Strahan D (2009) Extreme oil: scraping the bottom of Earth's barrel. New Sci 204(2737):34-39

Sukhdev P (2008) The economics of ecosystems \& biodiversity: an interim report. European Communities, Brussels

Sumaila UR (2002) Marine protected area performance in a model of a fishery. Nat Resour Model 15(4):439_ 451

TEEB (The Economics of Ecosystems and Biodiversity) (2009) The economics of ecosystems and biodiversity for national and international policy makers. www.teebweb.org

Tol RSJ (2005) The marginal damage costs of carbon dioxide emissions: an assessment of the uncertainties. Energy Policy 33(16):2064-2074

Treasury HM (2003) The green book: appraisal and evaluation in central government. The Stationery Office, London. Available at http://greenbook.treasury.gov.uk/

Troy A, Wilson MA (2006) Mapping ecosystem services: practical challenges and opportunities in linking GIS and value transfer. Ecol Econ 60:435-449. doi:10.1016/j.ecolecon.2006.04.007

Tschirhart J (2009) Integrated ecological-economic models. Ann Rev Resour Econ 1:381-407

Turner RK (1999) The place of economic values in environmental valuation. In: Bateman IJ, Willis KG (eds) Valuing environmental preferences. Oxford University Press, Oxford 
Turner RK, Pearce DW (1993) Sustainable economic development: economic and ethical principles. In: Barbier E (ed) Economics and ecology: new frontiers and sustainable development. Chapman and Hall, London, pp 177-194

Turner RK, Pearce DW, Bateman IJ (1994) Environmental economics: an elementary introduction. Harvester Wheatsheaf, Hemel Hempstead

Turner RK, Morse-Jones S, Fisher B (2010) Ecosystem valuation: a sequential decision support system and quality assessment issues. Ann N Y Acad Sci 1185:79-101

Turner RK, Paavola J, Cooper P, Farber S, Jessamy V, Georgiou S (2003) Valuing nature: lessons learned and future research directions. Ecol Econ 46:492-510

UKCIP (2001) Socio-economic scenarios for climate change impact assessment: a guide to their use in the UK climate impacts programme. United Kingdom Climate Impacts Programme, Oxford

United Nations (2003) The handbook of national accounting: integrated environmental and economic accounting 2003. United Nations, New York

Vatn A, Bromley DW (1994) Choices without prices without apologies. J Environ Econ Manage 26:129-148

Wallace KJ (2007) Classification of ecosystem services: problems and solutions. Biol Cons 139:235-246

Walker B, Pearson L, Harris M, Mäler K-G, Li C-Z, Biggs R, Baynes T (2010) Incorporating resilience in the assessment of inclusive wealth: an example from south east australia. Environ Resour Econ 45:183-202. doi: $10.1007 / \mathrm{s} 10640-009-9311-7$

Weitzman M (2007) A review of the stern review on the economics of climate change. J Econ Lit 45:703-724

Welsch H, Kuhling J (2008) Using happiness data for environmental valuation: issues and applications. J Econ Surv 23:385-406

Wilson MA, Howarth RB (2002) Discourse-based valuation of ecosystem services: establishing fair outcomes through group deliberation. Ecol Econ 41:431-443

Yachi S, Loreau M (1999) Biodiversity and ecosystem productivity in a fluctuating environment: the insurance hypothesis. Proc Natl Acad Sci 96:1463-1468

Zandersen M, Termansen M, Jensen FS (2007) Testing benefits transfer of forest recreation values over a twenty-year time horizon. Land Econ 83(3):412-440 